\title{
A broadband cavity enhanced absorption spectrometer for aircraft measurements of glyoxal, methylglyoxal, nitrous acid, nitrogen dioxide, and water vapor
}

\author{
K.-E. Min ${ }^{1,2, a}$, R. A. Washenfelder ${ }^{1,2}$, W. P. Dubé ${ }^{1,2}$, A. O. Langford ${ }^{2}$, P. M. Edwards ${ }^{1,2, b}$, K. J. Zarzana ${ }^{1,2}$, J. Stutz ${ }^{4}$,

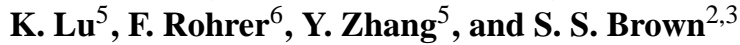 \\ ${ }^{1}$ Cooperative Institute for Research in Environmental Sciences, University of Colorado, Boulder, CO, USA \\ ${ }^{2}$ Chemical Sciences Division, Earth System Research Laboratory, National Oceanic and Atmospheric \\ Administration, Boulder, CO, USA \\ ${ }^{3}$ Department of Chemistry and Biochemistry, University of Colorado, Boulder, CO, USA \\ ${ }^{4}$ Department of Atmospheric and Oceanic Sciences, University of California, Los Angeles, CA, USA \\ ${ }^{5}$ College of Environmental Sciences and Engineering, Peking University, Beijing, China \\ ${ }^{6}$ Institute of Energy and Climate Research, IEK-8: Troposphere, Forschungszentrum Jülich GmbH, Jülich, Germany \\ ${ }^{a}$ now at: School of Environmental Science and Engineering, Gwangju Institute of Science and Technology, Gwangju, Korea \\ ${ }^{b}$ now at: Department of Chemistry, University of York, York, UK
}

Correspondence to: R. A. Washenfelder (rebecca.washenfelder@noaa.gov)

Received: 29 September 2015 - Published in Atmos. Meas. Tech. Discuss.: 29 October 2015

Revised: 26 January 2016 - Accepted: 27 January 2016 - Published: 11 February 2016

\begin{abstract}
We describe a two-channel broadband cavity enhanced absorption spectrometer (BBCEAS) for aircraft measurements of glyoxal (CHOCHO), methylglyoxal $\left(\mathrm{CH}_{3} \mathrm{COCHO}\right)$, nitrous acid $(\mathrm{HONO})$, nitrogen dioxide $\left(\mathrm{NO}_{2}\right)$, and water $\left(\mathrm{H}_{2} \mathrm{O}\right)$. The instrument spans 361-389 and $438-468 \mathrm{~nm}$, using two light-emitting diodes (LEDs) and a single grating spectrometer with a charge-coupled device (CCD) detector. Robust performance is achieved using a custom optical mounting system, high-power LEDs with electronic on/off modulation, high-reflectivity cavity mirrors, and materials that minimize analyte surface losses. We have successfully deployed this instrument during two aircraft and two ground-based field campaigns to date. The demonstrated precision $(2 \sigma)$ for retrievals of $\mathrm{CHOCHO}$, HONO and $\mathrm{NO}_{2}$ are 34, 350, and 80 parts per trillion (pptv) in $5 \mathrm{~s}$. The accuracy is $5.8,9.0$, and $5.0 \%$, limited mainly by the available absorption cross sections.
\end{abstract}

\section{Introduction}

Broadband cavity enhanced absorption spectroscopy (BBCEAS) belongs to a class of techniques that use highfinesse optical cavities to achieve sensitive measurements of optical extinction (Fiedler et al., 2003). BBCEAS is distinct from other techniques in this class, such as cavity ring-down spectroscopy (CRDS), because it employs an unmodulated broadband light source and a multichannel detector. Broadband measurements enable the simultaneous detection of multiple absorbing species across a wide spectral region, and the quantification of species with significant spectral overlaps in their features. The basic components of BBCEAS include a light source, collimating optics, high-finesse cavity with two high-reflectivity mirrors, and a multi-channel detector to monitor wavelength-dependent light changes inside the cavity.

Laboratory studies have used BBCEAS to measure a number of trace gases with structured absorption in the visible and ultraviolet spectral region, including $\mathrm{NO}_{2}, \mathrm{NO}_{3}, \mathrm{~N}_{2} \mathrm{O}_{5}$ (by thermal conversion to $\mathrm{NO}_{3}$ ), nitrous acid (HONO), water $\left(\mathrm{H}_{2} \mathrm{O}\right), \mathrm{H}_{2} \mathrm{O}_{2}, \mathrm{O}_{3}, \mathrm{O}_{4}, \mathrm{I}_{2}, \mathrm{IO}, \mathrm{OIO}, \mathrm{SO}_{2}$, glyoxal (CHO$\mathrm{CHO}$ ), and methylgloxal $\left(\mathrm{CH}_{3} \mathrm{COCHO}\right)$ (Ball et al., 2004; 
Venables et al., 2006; Gherman et al., 2008; Vaughan et al., 2008; Washenfelder et al., 2008; Langridge et al., 2009; Watt et al., 2009; Thalman and Volkamer, 2010; Axson et al., 2011; Chen and Venables, 2011; Kahan et al., 2012), as well as wavelength-dependent aerosol extinction (Thompson and Spangler, 2006; Washenfelder et al., 2008, 2013; Thalman and Volkamer, 2010; Varma et al., 2013). Groundand ship-based BBCEAS field instruments have been used to measure $\mathrm{CHOCHO}$ and $\mathrm{NO}_{2}$ (Washenfelder et al., 2011a; Coburn et al., 2014), $\mathrm{HONO}$ and $\mathrm{NO}_{2}$ (Washenfelder et al., 2011a; Young et al., 2012), $\mathrm{NO}_{3}$, and $\mathrm{N}_{2} \mathrm{O}_{5}$ (Benton et al., 2010). Kennedy et al. (2011) have recently described an aircraft BBCEAS instrument to measure $\mathrm{NO}_{2}, \mathrm{NO}_{3}$, and $\mathrm{N}_{2} \mathrm{O}_{5}$. Based on this history, $\mathrm{CHOCHO}$ and $\mathrm{HONO}$ are promising targets for aircraft BBCEAS measurements. Aircraft measurements of trace gases are important to satellite validation; understanding vertical concentration profiles; characterization of chemical lifetimes, processing, and transport; quantification of emissions and deposition; and the study of chemical mechanisms.

Glyoxal is the simplest alpha-dicarbonyl and is one of the most prevalent dicarbonyls in the ambient atmosphere. Global models indicate that its major source is oxidation of biogenic compounds, led by isoprene (47\%) with smaller contributions from monoterpenes $(4 \%)$ and methylbutenol $(0.8 \%)$ (Fu et al., 2008). Other important glyoxal sources include the oxidation of anthropogenic species, such as ethyne and aromatics $(30 \%)$, and direct production from biomass burning (18\%) (Fu et al., 2008). However, these global estimates are uncertain, in part because of the limited number of ambient measurements of glyoxal. For example, enhanced glyoxal concentrations over the equatorial ocean have recently been reported from satellite and ship-based instruments, indicating a source of $\mathrm{CHOCHO}$ from the oxidation of marine emissions (Sinreich et al., 2010; Mahajan et al., 2014). The major loss processes for glyoxal include photolysis, reaction with $\mathrm{OH}$ and $\mathrm{NO}_{3}$, and deposition to aerosol and ground surfaces. Laboratory studies have reached different conclusions about the magnitude and reversibility of glyoxal's contribution to secondary organic aerosol mass (Jang et al., 2002; Hastings et al., 2005; Kroll et al., 2005; Liggio et al., 2005; Nakao et al., 2012), while field studies have also drawn inconsistent conclusions about the importance of glyoxal to aerosol mass budgets (Volkamer et al., 2007; Washenfelder et al., 2011a). Previously, remote sensing measurements of ambient glyoxal concentrations have been reported using long-path differential optical absorption spectroscopy (DOAS) (Volkamer et al., 2005a; MacDonald et al., 2012) and multi-axis DOAS (MAX-DOAS) (Sinreich et al., 2007), including MAX-DOAS measurements from aircraft (Baidar et al., 2013; Volkamer et al., 2015). The few successful techniques for in situ measurements include high-pressure liquid chromatography or gas chromatography (Munger et al., 1995; Grosjean et al., 2002), laser-induced phosphorescence (Huisman et al., 2008), BBCEAS (Washen- felder et al., 2011a), and the related cavity enhanced DOAS (CE-DOAS) technique (Coburn et al., 2014). Methylglyoxal $\left(\mathrm{CH}_{3} \mathrm{COCHO}\right)$ is a similar alpha-dicarbonyl species that may also be an important source of secondary organic aerosol mass (Kalberer et al., 2004; Lin et al., 2012). Global models indicate that the major source of methylglyoxal is isoprene (79\%), followed by acetone (7\%) and direct emissions (4\%) (Fu et al., 2008). The uncertainty in the sources and sinks of glyoxal and methylglyoxal underscores the need for rapid, accurate, in situ measurements.

Similarly, there is a need for accurate, rapid, in situ measurements of HONO, which plays an important role in atmospheric radical budgets through photolytic production of $\mathrm{OH}$ radicals and NO (Platt et al., 1980; Alicke et al., 2002). Scientific questions remain about its sources, sinks, and vertical profile (Zhou et al., 1999; Su et al., 2008; Young et al., 2012; VandenBoer et al., 2013). Existing detection methods can be categorized as wet chemistry, mass spectrometry, and optical spectroscopy. The wet chemical detection methods are sensitive but generally rely on conversion of HONO to nitrite ion $\left(\mathrm{NO}_{2}^{-}\right.$) (Appel et al., 1990; Dibb et al., 2002; Kleffmann et al., 2006) and may be susceptible to chemical interferences and sampling artifacts (Stutz et al., 2010). Recently, chemical ionization mass spectrometry with acetate ion (Roberts et al., 2010) or iodide ion (Veres et al., 2015) chemistry has been successfully used for sensitive HONO detection. Spectroscopic methods for remote sensing include long-path DOAS and MAX-DOAS (Platt et al., 1980; Hendrick et al., 2014). In situ spectroscopic detection methods include cavity ringdown spectroscopy (Wang and Zhang, 2000), tunable diode laser spectroscopy (Li et al., 2008; Lee et al., 2011), and Fourier transform spectroscopy (Barney et al., 2000; Yokelson et al., 2007), although limited attempts have been made for field deployment. BBCEAS has been used successfully for ground-based measurements of HONO (Washenfelder et al., 2011a; Young et al., 2012).

Here, we present a new aircraft BBCEAS instrument, the Airborne Cavity Enhanced Spectrometer (ACES) and describe its use to measure $\mathrm{CHOCHO}, \mathrm{HONO}, \mathrm{NO}_{2}$, $\mathrm{CH}_{3} \mathrm{COCHO}$, and $\mathrm{H}_{2} \mathrm{O}$. This instrument follows the development of laboratory and ground-based BBCEAS field instruments by our group (Washenfelder et al., 2008, 2011a; Young et al., 2012), with significant improvements in engineering and data acquisition that allow rapid, precise aircraft sampling. This is the first instrument for in situ measurements of $\mathrm{CHOCHO}$ from an aircraft. The HONO measurement is lower in precision than that of $\mathrm{CHOCHO}$ due to lower cavity mirror reflectivity and narrower light-emitting diode (LED) spectral output, but it is sufficient for aircraft measurements under high signal conditions, such as in biomass burning plumes. The ACES instrument was successfully deployed during the SouthEast NEXus (SENEX) 2013 and the Shale Oil and Natural Gas Nexus (SONGNEX) 2015 aircraft studies, where it operated on the NOAA WP-3D aircraft at altitudes from 0 to $7 \mathrm{~km}$ and flight durations of $6-7 \mathrm{~h}$. In ad- 

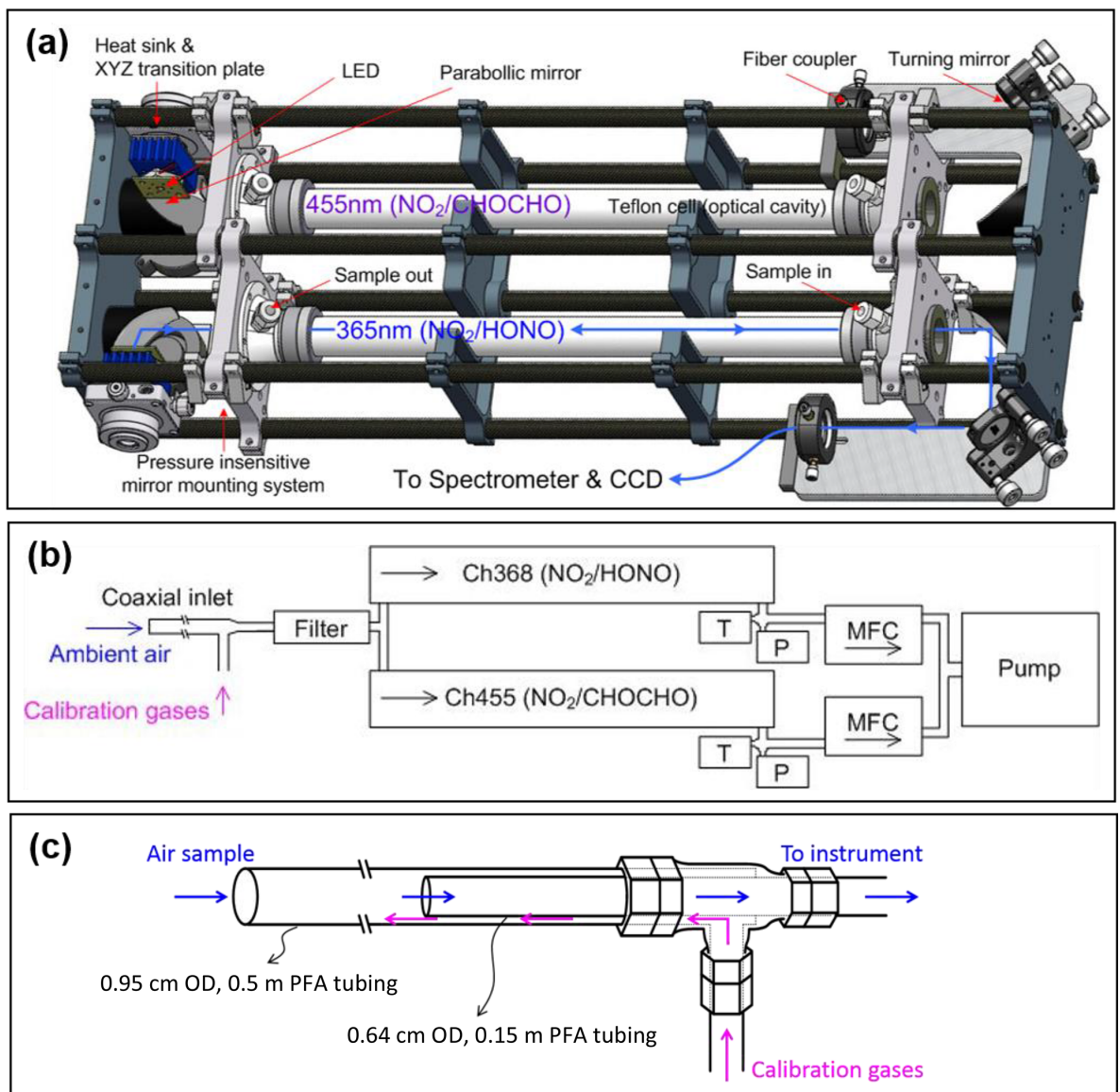

Figure 1. (a) ACES optical system, showing the LEDs, collimating optics, and high-finesse cavities defined by the high-reflectivity mirrors. The system is mounted on six carbon rods to achieve an optical alignment that is insensitive to vibration and pressure changes. (b) ACES flow system, showing the inlet, aerosol filter, two cells, temperature $(T)$ and pressure $(P)$ sensors, mass flow controllers (MFC), and pump. (c) ACES inlet system, consisting of an outer Teflon FEP tube $(0.95 \mathrm{~cm}$ OD, $0.79 \mathrm{~cm}$ ID, $0.5 \mathrm{~m}$ long) and coaxial inner Teflon FEP tube $(0.64 \mathrm{~cm}$ OD, $0.15 \mathrm{~m}$ long). The coaxial design allows calibration gases to be added without affecting the inlet pressure.

dition, ACES has been deployed to measure ambient $\mathrm{CHO}-$ $\mathrm{CHO}$ and HONO during two ground-based field campaigns: the Campaigns of Air Quality Research in Beijing and Surrounding Regions in the North China Plain (CARE BeijingNCP) 2014 and the Uintah Basin Winter Ozone Study (UBWOS) 2014. Section 2 describes the instrument in detail. We present data from the SENEX 2013 and CARE Beijing-NCP 2014 studies in Sects. 3 and 4.

\section{Experimental description of the ACES instrument}

The ACES optical system, flow system, electronics, cell materials, and operation are described in detail in this section. The instrument builds on our previous ground-based field instrument (Washenfelder et al., 2011a), with numerous improvements to achieve robust performance in a demanding flight environment subject to vibration and rapid changes in ambient temperature and pressure.
The ACES instrument has two channels, as shown in Fig. 1a, with wavelength coverage from 361 to 389 and 438 to $468 \mathrm{~nm}$ (hereafter $\mathrm{Ch} 368$ and $\mathrm{Ch} \mathrm{455).} \mathrm{The} \mathrm{wavelength}$ range is determined by the LED spectral radiance, the center wavelength and bandwidth of the cavity mirrors, as well as the wavelength-dependent absorption features of the target gases (Fig. 2). $\mathrm{HONO}$ and $\mathrm{NO}_{2}$ are detected in $\mathrm{Ch} 368$, while $\mathrm{CHOCHO}, \mathrm{CH}_{3} \mathrm{COCHO}, \mathrm{NO}_{2}$, and $\mathrm{H}_{2} \mathrm{O}$ are detected in $\mathrm{Ch} 455$. In the future, the instrument could be expanded to detect other trace gases with absorption features in these spectral regions, such as IO, or other trace gases in different spectral regions by replacing the LEDs and cavity mirrors.

\subsection{Optical system}

The optical system is shown schematically in Fig. 1a and technical details for the components are given in Table 1. Two LEDs (Ch 368: NCSU033B, Nichia Corp., Tokyo, Japan; Ch 455: LZ1-00DB05, LedEngin Inc., San Jose, 
Table 1. ACES instrumental details and measurement accuracy

\begin{tabular}{|c|c|c|}
\hline & Ch 368 (Channel 1) & Ch 455 (Channel 2) \\
\hline Species & $\mathrm{NO}_{2}, \mathrm{HONO}, \mathrm{O}_{4}$ & $\mathrm{NO}_{2}, \mathrm{CHOCHO}, \mathrm{CH}_{3} \mathrm{COCHO}, \mathrm{H}_{2} \mathrm{O}, \mathrm{O}_{4}$ \\
\hline LED power & $\begin{array}{l}\text { Nichia, NCSU033B } \\
0.45 \mathrm{~W}\end{array}$ & $\begin{array}{l}\text { LedEngin, LZ1-00DB05 } \\
1 \mathrm{~W}\end{array}$ \\
\hline Fitted wavelength range & $361-389 \mathrm{~nm}$ & $438-468 \mathrm{~nm}$ \\
\hline Mirror reflectivity & $\begin{array}{l}\text { Advanced Thin Films } \\
99.984 \% \text { at } 368 \mathrm{~nm}\end{array}$ & $\begin{array}{l}\text { Advanced Thin Films } \\
99.9973 \% \text { at } 455 \mathrm{~nm}\end{array}$ \\
\hline Cell length & $48 \mathrm{~cm}$ & $48 \mathrm{~cm}$ \\
\hline Effective path length & $3.0 \mathrm{~km}$ at $368 \mathrm{~nm}$ & $17.8 \mathrm{~km}$ at $455 \mathrm{~nm}$ \\
\hline Bandpass filter & $\begin{array}{l}\text { Omega Optical Inc, XB05 } \\
360 \pm 50 \mathrm{~nm}\end{array}$ & $\begin{array}{l}\text { Thorlabs, FB450-40 } \\
450 \pm 20 \mathrm{~nm}\end{array}$ \\
\hline FWHM $^{1}$ & $0.8 \mathrm{~nm}$ at $368 \mathrm{~nm}$ with $200 \mu \mathrm{m}$ slit & $1.02 \mathrm{~nm}$ at $455 \mathrm{~nm}$ with $200 \mu \mathrm{m}$ slit \\
\hline Accuracy & $\begin{array}{l}\mathrm{NO}_{2} \pm 4.6 \% \\
\mathrm{HONO} \pm 9.0 \% \\
\mathrm{O}_{4} \pm 10.2 \%\end{array}$ & $\begin{array}{l}\mathrm{NO}_{2} \pm 5.0 \% \\
\mathrm{CHOCHO} \pm 5.8 \% \\
\mathrm{CH}_{3} \mathrm{COCHO} \pm 15.2 \% \\
\mathrm{H}_{2} \mathrm{O} \pm 4.6 \% \\
\mathrm{O}_{4} \pm 10.2 \%\end{array}$ \\
\hline
\end{tabular}

${ }^{1}$ FWHM is determined from the $\mathrm{Hg} / \mathrm{Ar}$ lamp measurement

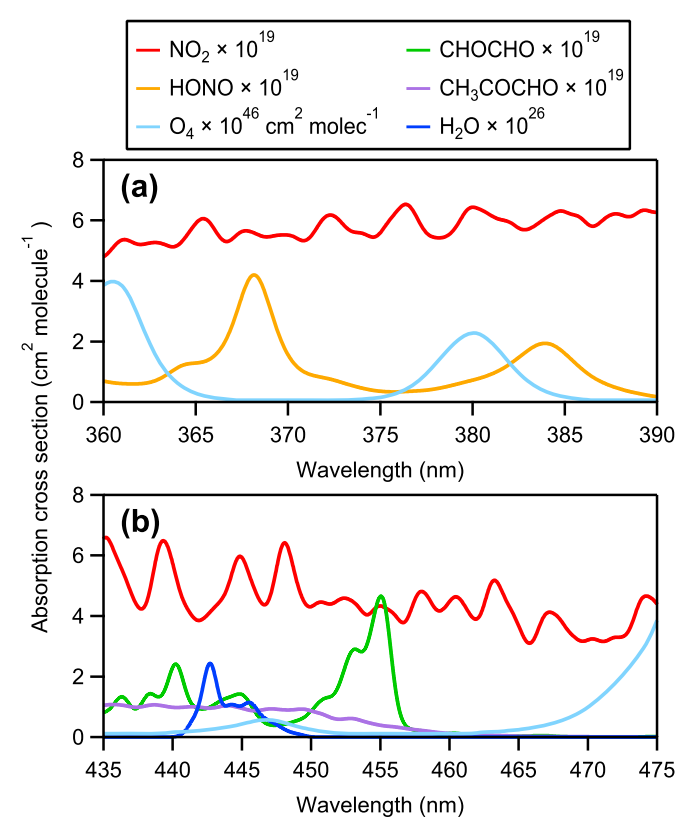

Figure 2. Convolved literature absorption cross sections shown for the ACES wavelength range for (a) $\mathrm{Ch} 368: \mathrm{NO}_{2}, \mathrm{HONO}$, and $\mathrm{O}_{4}$; and (b) $\mathrm{Ch} 455: \mathrm{NO}_{2}, \mathrm{CHOCHO}, \mathrm{CH}_{3} \mathrm{COCHO}, \mathrm{H}_{2} \mathrm{O}$, and $\mathrm{O}_{4}$.

CA, USA) are separately temperature-controlled using thermoelectric coolers. Their output light is collimated using off-axis parabolic mirrors (50328AL, $2.0 \mathrm{~cm}$ effective focal length, Newport Corp., Irvine, CA, USA) prior to entering each cell. The off-axis parabolic mirrors optimize both photon throughput and space efficiency. The light is coupled into a high-finesse cavity formed by high-reflectivity mirrors (1$\mathrm{m}$ radius of curvature, Advanced Thin Films, Boulder, CO, USA), which are separated by $48 \mathrm{~cm}$. The difference in sensitivity between this design and a confocal mirror separation is negligible (Wild et al., 2014).

The light exiting the cavity is imaged by an off-axis parabolic mirror (50331AL, $15.2 \mathrm{~cm}$ effective focal length, Newport Corp., Irvine, CA, USA) through a band pass filter onto a $0.5 \mathrm{~cm} \mathrm{~F} / 2$ lens that couples the light into a $1 \mathrm{~m}$ UV/VIS fiber optic bundle. The bundle contains two groups of seven $200 \mu \mathrm{m}$ diameter fibers (BFB-455-7, Princeton Instruments, Trenton, NJ, USA) that are linearly aligned on the slit axis of a $150 \mathrm{~mm}$ focal length $\mathrm{f} / 4.0$ grating spectrometer (SP2150, Princeton Instruments, Trenton, NJ, USA). Each BBCEAS channel illuminates one group of fibers, so that the light from the two channels is imaged onto two separated, vertical regions of the charge-coupled device (CCD) detector. The CCD detector has $2048 \times 512$ pixels and $\mathrm{a}-70^{\circ} \mathrm{C}$ cooling capacity (PIXIS2KBUV, Princeton Instruments, Trenton, NJ, USA). The spectrometer contains a 1200 groove $\mathrm{mm}^{-1}$ ( $500 \mathrm{~nm}$ blaze) grating centered at $418 \mathrm{~nm}$, with spectral coverage of $119 \mathrm{~nm}$. Two regions of interest $(2048 \times 128$ pixels each) are defined based on the illumination of the CCD. In addition, a dark region of the CCD $(2048 \times 50$ pixels $)$ between the two regions of interest is recorded to monitor photon diffusion among adjacent pixels and light scattering inside of the spectrometer. 
The CCD must be darkened while the accumulated charge is moved across the semi-conductor surface to a readout amplifier and analog-to-digital converter. This would typically be achieved using a mechanical shutter that requires $\sim 8 \mathrm{~ms}$ to open and close, and can fail after rapid, continuous operation. To improve our instrument duty cycle and reliability, we electronically modulate the optical output of the LEDs using a square-wave modulation and read out the CCD signal while the LEDs are dark. The LEDs are illuminated for $0.4 \mathrm{~s}$, followed by $0.078 \mathrm{~s}$ when the LEDs are dark $(0.006 \mathrm{~s}$ compensation time and $0.072 \mathrm{~s}$ CCD readout time), giving a total duty cycle of $84 \%$. We further improve the duty cycle and signal-to-noise ratio with a low readout amplification (gain: $16 \mathrm{e}^{-}$count $^{-1}$, digitization speed: $2 \mathrm{MHz}$ ) and a CCD temperature of $-50{ }^{\circ} \mathrm{C}$. While the LEDs are dark, the accumulated charge for the three spectral regions is sequentially transferred to the CCD readout amplifier and analogto-digital converter, resulting in three separate spectra.

For automated wavelength and lineshape calibrations, we use a Hg lamp (HG-1, Ocean Optics, Dunedin, FL, USA) with a custom adapter located between the band pass filter and fiber optic bundle to introduce $\mathrm{Hg}$ light without obscuring the main beam path. A fused silica window (Edmund Optics, Barrington, NJ, USA) mounted at $45^{\circ}$ inside the adaptor reflects $\mathrm{Hg}$ light to illuminate the fiber optic during wavelength calibrations. The spectrometer wavelength calibration and lineshape are calculated from four narrow $\mathrm{Hg}$ lines at 365.02, 404.66, 407.78, and 435.83 nm (air wavelengths; Sansonetti et al., 1996), assuming a Gaussian lineshape.

\subsection{Cage system and hardware}

As shown in Fig. 1a, the optical components are mounted in a cage system, measuring $63 \times 29 \times 13 \mathrm{~cm}$. The cage system consists of carbon fiber rods with $1.25 \mathrm{~cm}$ outside diameter (OD) and mounts for each optical component attached to the rods (Wild et al., 2014). Custom-designed aluminum plates aligned and locked parallel to each other on the carbon rods provide robust alignment without the use of springloaded, commercial mirror mounts. As shown in Fig. 1a, the final alignment of each aluminum plate can be adjusted using fine adjustment screws (F6SS058; Thorlabs, Newton, NJ, USA) that are locked to the carbon rods at opposing corners of the plate. Following the fine adjustment, the aluminum plates are secured to the carbon rods using splitclamp mounts. The cavity mirrors are sealed to the cage system using compressed O-rings that allow the mirror face to fully contact the metal plate, eliminating variable compression of the O-ring with cell pressure and minimizing pressure sensitivity. This system provides stable optical alignment that does not require re-alignment and is insensitive to vibration, pressure, or temperature changes. The optical cavity, spectrometer, and CCD are mounted in a temperature-controlled box, which is maintained at 30 or $35^{\circ} \mathrm{C}$ using thermoelectric coolers.

\subsection{Flow system}

The flow system for ACES includes the inlet, aerosol filter, two cells, pressure sensors, temperature sensors, mass flow controllers, and pump. It is shown schematically in Fig. 1b and described in further detail below.

The inlet consists of two parts: a coaxial inlet designed for overflow by calibration gases and a filter to remove aerosols. All inlet tubing is Teflon fluorinated ethylene propylene (FEP), because Teflon provided the best CHOCHO transmission efficiency in laboratory tests (see Sect. 2.4). The coaxial inlet consists of $0.95 \mathrm{~cm}$ OD tubing $(0.35 \mathrm{~m}$ length, $0.79 \mathrm{~cm}$ ID), which contains $0.64 \mathrm{~cm}$ OD tubing $(0.15 \mathrm{~m}$ length), as shown in Fig. 1c. The $0.64 \mathrm{~cm}$ OD tubing runs through the Teflon perfluoroalkoxy polymer resin (PFA) tee to allow additions of calibration gases (Wagner et al., 2011). The calibration gas flow is $0.3-0.5 \mathrm{sL} \mathrm{min}^{-1}$ (standard liter per minute) greater than the total sample flow rate of $5.0 \mathrm{sL} \mathrm{min}^{-1}$. During aircraft sampling, the total length of the coaxial inlet is $1.5 \mathrm{~m}$ and it is contained in a winglet that extends outside the boundary layer of the aircraft.

A Teflon polytetrafluoroethylene (PTFE) membrane filter ( $25 \mu \mathrm{m}$ thickness, $4.6 \mathrm{~cm}$ diameter, $1 \mu \mathrm{m}$ pore size; Tisch Environmental, Cleves, OH, USA) is installed downstream of the coaxial inlet to remove ambient aerosol because aerosol extinction limits the effective path length and adds a variable background extinction. The filter is changed prior to each $8 \mathrm{~h}$ aircraft flight and once or twice per day for ground-based measurements. Ground-based data were examined for discontinuities in $\mathrm{CHOCHO}$ or HONO before and after a filter change, and no discrepancies were observed within the measurement precision. Prior experience with $\mathrm{NO}_{2}$ (Osthoff et al., 2006; Wagner et al., 2011) and CHOCHO (Washenfelder et al., 2011a) suggest that aerosol filters transmit these compounds quantitatively.

After the filter, the flow is evenly divided to two sample cells constructed of Teflon PTFE $(2.5 \mathrm{~cm}$ OD, $1.5 \mathrm{~cm}$ ID, $40 \mathrm{~cm}$ length). Unlike in previous designs (Wagner et al., 2011; Washenfelder et al., 2013), the ACES instrument does not include mirror purges of dry gas for mirror cleanliness. The mirror purges were found to be unnecessary during SENEX, SONGNEX, and UBWOS due to a combination of reduced cell pressure, aerosol filtration, and cell temperature (controlled at $30^{\circ} \mathrm{C}$ ), and their absence eliminates the small uncertainties from flow dilution and the relative sample length occupied by sample gas and purge gas over the length of the cavity. During CARE Beijing-NCP, the mirrors required daily cleaning due to compromised reflectivity, likely due to high concentrations of organic species, high relative humidity, and high ambient temperatures. 
Table 2. Glyoxal losses measured for different tubing materials.

\begin{tabular}{lrr}
\hline Material & $\begin{array}{r}\text { Surface } \\
\text { description }\end{array}$ & $\begin{array}{r}\text { Glyoxal loss } \\
\left(\% \mathrm{~cm}^{-2} \mathrm{~s}^{-1}\right)\end{array}$ \\
\hline Aluminum - alloy 3003 & Polished & $0.023( \pm 0.005)$ \\
Aluminum - alloy 5052 & Polished & $0.072( \pm 0.004)$ \\
Aluminum - alloy 6061 & Polished & $0.081( \pm 0.004)$ \\
Aluminum - alloy 6061 & Unpolished & $0.141( \pm 0.004)$ \\
Glass & & $0.211( \pm 0.006)$ \\
Polyoxymethylene (Delrin) & & $0.025( \pm 0.004)$ \\
Stainless steel - alloy 316 & & $0.018( \pm 0.005)$ \\
Stainless steel - alloy 316 & Seamless & $0.014( \pm 0.006)$ \\
Teflon FEP & & $0.0001( \pm 0.005)$ \\
Titanium & & $0.043( \pm 0.005)$ \\
\hline
\end{tabular}

The cells are connected to separate mass flow controllers (MC-50SLPM-D-DB15B, Alicat Scientific, Inc., Tucson, AZ, USA) and a scroll pump (IDP-3, Agilent Technologies, Inc., Santa Clara, CA, USA) to maintain a constant flow rate of $2.5 \mathrm{sL} \mathrm{min}{ }^{-1}$, resulting in a residence time less than $1.5 \mathrm{~s}$ in each cell. This flow rate and residence time were consistent with the data acquisition rate and minimized $\mathrm{He}$ and zero air (ZA) consumption during reference measurements. The cell pressures (PPT, Honeywell International Inc., Plymouth, MN, USA) and temperatures (KMQSS-020U-6, Omega Engineering Inc., Stamford, CT, USA) are measured immediately downstream of the flow.

The cavity loss (or effective optical path length) was measured by sequentially overflowing the inlet with $\mathrm{He}$ and ZA from compressed gas cylinders or by acquiring zero air measurements at different pressures. Further details are given in Sect. 3.1.

\subsection{Flow system materials}

Surface reactions on flow system materials can potentially cause production or loss of target analytes, affecting the accuracy of in situ measurements. Previous tests have demonstrated that $\mathrm{NO}_{2}$ has negligible losses on Teflon and metal surfaces (Osthoff et al., 2006; Fuchs et al., 2009). Prior measurements have shown that inlet length has negligible impact on glyoxal losses for PTFE tubing (Huisman et al., 2008) and that ozone addition to a Teflon inlet does not produce glyoxal or methylglyoxal (Thalman et al., 2015).

We measured glyoxal losses for 10 materials to determine the best cell and tubing choices. For the tests, we configured both BBCEAS channels to measure $\mathrm{CHOCHO}$, with the cells connected in series and a length of tubing between them. Losses between the two cells were attributed to the tubing material. Constant $\mathrm{CHOCHO}$ concentrations were generated from a temperature-controlled Teflon bubbler (Savillex, Eden Prairie, MN, USA) filled with CHOCHO solution (40 weight percent in water; Sigma Aldrich, St. Louis, MO, USA). Each test section was $1.0 \pm 0.1 \mathrm{~cm}$ ID and $92 \pm 2 \mathrm{~cm}$ long. Table 2 lists the 10 tubing materials and their measured losses, in units of fractional loss per unit tubing surface area per residence time $\left(\% \mathrm{~cm}^{-2} \mathrm{~s}^{-1}\right)$. Teflon FEP showed the smallest loss $\left(0.0001 \pm 0.005 \% \mathrm{~cm}^{-2} \mathrm{~s}^{-1}\right)$, while glass tubing had greatest loss $\left(0.211 \pm 0.006 \% \mathrm{~cm}^{-2} \mathrm{~s}^{-1}\right)$. Finishing methods also affected the loss rate, with lower losses by polished metal surfaces compared to unpolished metal surfaces. We calculate the total loss of $\mathrm{CHOCHO}$ from the surface area and residence time of individual components of the ACES sample system to be less than $0.1 \%$, even for inlet tubing of $10 \mathrm{~m}$ in length and $0.79 \mathrm{~cm}$ ID with $5 \mathrm{sL} \mathrm{min}^{-1}$ flow. The relative humidity during these experiments was low $(<20 \%)$ and constant. At elevated relative humidity, the losses may be greater, although we expect this to be a small effect (Washenfelder et al., 2008) and did not observe a dependence of the CHOCHO / HCHO ratio on relative humidity during SENEX 2013 that would indicate inlet effects. Actual inlet lengths were $1.5 \mathrm{~m}$ for aircraft sampling during SENEX and SONGNEX, 3-12 $\mathrm{m}$ for ground-based sampling during CARE Beijing, and $6.5 \mathrm{~m}$ for ground-based sampling during UBWOS 2014.

\subsection{Operation of the ACES instrument}

During aircraft operation, the ACES instrument is typically turned on $1 \mathrm{~h}$ prior to flight, allowing the LEDs, optics box, and CCD to stabilize in temperature. The CCD dark background is characterized by acquiring 50 spectra under dark conditions with the same integration time as the subsequent measurements. This is necessary because the CCD produces non-zero signal under optically dark conditions. At the beginning and end of each flight, we measure dark background spectra, $\mathrm{Hg}$ spectra for wavelength calibration and instrument lineshape, and standard additions of $\mathrm{NO}_{2}$ and $\mathrm{CHO}-$ $\mathrm{CHO}$. The inlet filter is changed before and after each flight.

During flight, ZA is introduced for $30 \mathrm{~s}$ every $5 \mathrm{~min}$, while $\mathrm{He}$ is introduced for $30 \mathrm{~s}$ every $15 \mathrm{~min}$ for calibrating mirror reflectivity. During ground-based operation, the gas additions are 30-60 s in duration, depending on the inlet length. Inlet filter change, dark background, and $\mathrm{Hg}$ wavelength and instrument lineshape measurements are performed once or twice per day.

\section{Data analysis}

\subsection{Determination of cavity loss and trace gas extinction}

BBCEAS instruments measure steady-state light intensity transmitted through an optical cavity. The light attenuation inside the cavity includes (1) absorption, scattering, and transmission losses by the cavity mirrors, (2) Rayleigh scattering by gas within the cavity, (3) absorption by trace gases, and (4) Mie scattering by particles. A general expression de- 
scribing the sum of the extinction is

$$
\begin{aligned}
\sum_{i}^{n} \alpha_{i}(\lambda)= & R_{\mathrm{L}}\left(\frac{(1-R(\lambda))}{d}+\alpha(\lambda)_{\text {Rayleigh }}\right) \\
& \left(\frac{I_{0}(\lambda)-I(\lambda)}{I(\lambda)}\right),
\end{aligned}
$$

where $\alpha_{i}(\lambda)$ is extinction by the $i$ th component, $\lambda$ is the wavelength of light, $R_{\mathrm{L}}$ is the ratio of the total cell length to the sample length, $d$ is the cavity length, $R(\lambda)$ is the mirror reflectivity, $I_{0}(\lambda)$ is the reference spectrum (without absorbing trace gases or aerosols and at the same temperature and pressure as the sample spectrum), and $I(\lambda)$ is the measured spectrum of ambient air, including trace gas absorptions, as a function of wavelength (Washenfelder et al., 2008).

The ACES instrument has no mirror purges, so $R_{\mathrm{L}}$ is unity. We define $I_{0}(\lambda)$ as the reference zero air spectrum so that the term $\alpha(\lambda)_{\text {Rayleigh }}$ explicitly includes its Rayleigh scattering. For aircraft measurements, we must also explicitly account for the difference between the Rayleigh scattering of the reference zero air spectrum, $I_{\mathrm{ZA}}(\lambda)$, and sample spectrum, $I_{\text {sample }}(\lambda)$, due to pressure differences during sampling. Incorporating these changes gives

$$
\begin{aligned}
\sum_{i}^{n} \alpha_{i, \text { sample }}(\lambda)= & \left(\frac{(1-R(\lambda))}{d}+\alpha_{\text {Ray }, \mathrm{ZA}}(\lambda)\right) \\
& \left(\frac{I_{\mathrm{ZA}}(\lambda)-I_{\text {sample }}(\lambda)}{I_{\text {sample }}(\lambda)}\right)+\Delta \alpha_{\text {Ray }}(\lambda),
\end{aligned}
$$

where $\quad \Delta \alpha_{\text {Ray }}(\lambda)=\alpha_{\text {Ray, ZA }}(\lambda)-\alpha_{\text {Ray, sample }}(\lambda) . \quad$ The $\alpha_{i \text {, sample }}(\lambda)$ summation on the left-hand side of Eq. (2) includes only absorption by gas-phase species, because aerosol particles are eliminated by the Teflon inlet filter. This term can be rewritten as

$$
\sum_{i}^{n} \alpha_{i, \text { sample }}(\lambda)=\sum_{i}^{n} \sigma_{i}(\lambda) N_{i},
$$

where $\sigma_{i}$ and $N_{i}$ are the absorption cross section and number density for the $i$ th trace absorber.

Accurate measurements of the trace gas absorption by BBCEAS require calibration of mirror reflectivity, $R(\lambda)$, or the cavity loss, which represents the inverse of the effective path length and is defined as $\alpha_{\text {cavity }}(\lambda)=(1-R(\lambda)) / d$. This quantity can be determined by introducing a species with well-known extinction into the cavity. For example, previous studies have used known Rayleigh scattering cross sections of $\mathrm{He}$ and $\mathrm{N}_{2}$ or ZA (Washenfelder et al., 2008; Thalman and Volkamer, 2010) or $\mathrm{N}_{2}$ and $\mathrm{N}_{2} / \mathrm{NO}_{2}$ mixtures (Langridge et al., 2006; Venables et al., 2006). We have tested and compared two methods to determine $\alpha_{\text {cavity }}(\lambda)$. First, we have compared Rayleigh scattering extinction in ZA relative to that in $\mathrm{He}$ (referred to as $\mathrm{He} / \mathrm{ZA}$ in the following text). Second, we have used ZA spectra acquired at different known pressures (referred to as ZA/ZA in the following text). The second method is possible because the ACES cage system maintains its optical alignment during pressure changes, and it has the advantage of eliminating the need for He gas cylinders. To our knowledge, this method has not been reported previously.

Empirical expressions for Rayleigh scattering cross section were determined using fits to Bodhaine et al. (1999) for $\mathrm{N}_{2}\left(\sigma_{\text {Rayleigh, } \mathrm{N}_{2}}=1.2577 \times 10^{-15} \times \lambda^{-4.1814}\right)$, Shardanand and Rao (1977) and Sneep and Ubachs (2005) for $\quad \mathrm{O}_{2} \quad\left(\sigma_{\text {Rayleigh, } \mathrm{O}_{2}}=1.0455, \times 10^{-15} \times \lambda^{-4.1814}\right)$, and Shardanand and Rao (1977) for $\mathrm{He}$ $\left(\sigma_{\text {Rayleigh, } \mathrm{He}}=1.336 \times 10^{-17} \times \lambda^{-4.1287}\right)$. Rayleigh scattering cross sections recently reported by Thalman et al. (2014) were not used in the calculations here but will be evaluated for future retrievals.

\subsection{Determination of trace gas concentrations}

Both published and measured reference spectra have been used to fit the number density of each absorber according to Eq. (3). For the literature absorption cross sections, highresolution laboratory references were used for $\mathrm{NO}_{2}$ (Vandaele et al., 2002), CHOCHO (Volkamer et al., 2005b), $\mathrm{CH}_{3} \mathrm{COCHO}$ (Staffelbach et al., 1995), $\mathrm{H}_{2} \mathrm{O}$ (Harder and Brault, 1997), $\mathrm{O}_{4}$ (Greenblatt et al., 1990), and HONO (Stutz et al., 2000).

Literature reference spectra were convolved with a Gaussian lineshape of full width at half maximum determined from $\mathrm{Hg}$ calibration lines, which was $0.82 \mathrm{~nm}$ for $\mathrm{Ch} 368$ and $1.02 \mathrm{~nm}$ for $\mathrm{Ch} 455$. The convolved literature reference spectra are shown in Fig. 2 for the relevant wavelength regions. Measured reference spectra were determined from $\mathrm{NO}_{2}$ and $\mathrm{CHOCHO}$ additions as described in Sect. 4.4, and these were used for the Ch 455 spectral retrievals. Measured reference spectra can be used to achieve more precise fits, because they are acquired with an identical instrument lineshape as the ambient measurements. However, it is necessary to carefully consider the accuracy of the measured reference spectra and the presence of trace gas contaminants, both of which may introduce errors into the spectral fitting.

The number density of trace gases was determined using least-squares, DOAS-style fit retrievals (Platt and Stutz, 2008) with DOASIS fitting software (Kraus, 2006). The fitted absorbers were $\mathrm{HONO}, \mathrm{NO}_{2}$ and $\mathrm{O}_{4}$ for $\mathrm{Ch} 368$, and $\mathrm{CHOCHO}, \mathrm{CH}_{3} \mathrm{COCHO}, \mathrm{NO}_{2}, \mathrm{H}_{2} \mathrm{O}$, and $\mathrm{O}_{4}$ for $\mathrm{Ch} 455$. In addition, a third- or fourth-order polynomial was included in each fit to account for drift in the light intensity and cavity throughput of the measurement. Stretch and shift of the reference spectra wavelength were included as fit parameters to minimize discrepancies with the wavelength calibration of the grating spectrometer, which may be caused by physical shifts in the spectrometer optics. For Ch 368, the measured $\mathrm{NO}_{2}$ reference spectra was shifted and stretched to minimize the fit residual, with equivalent values prescribed for the $\mathrm{HONO}$ and $\mathrm{O}_{4}$ reference spectra. For $\mathrm{Ch} 455$, the 

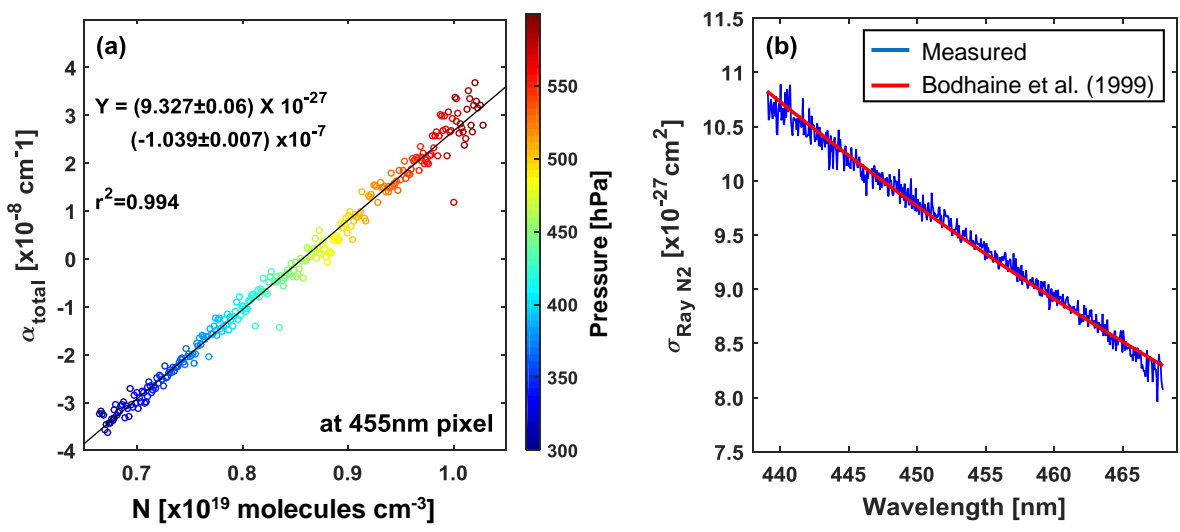

Figure 3. (a) Measured extinction at $455 \mathrm{~nm}$ vs. number density for a $\mathrm{N}_{2}$-filled cavity with varying pressure. The slope represents a Rayleigh scattering cross section $\left(\sigma_{\text {Rayleigh, N2 }}\right)$ at $455 \mathrm{~nm}$ of $(9.33 \pm 0.06) \times 10^{-27} \mathrm{~cm}^{2}$. (b) Measured wavelength-dependent $\sigma_{\text {Rayleigh, }} 2$ at $438-$ $468 \mathrm{~nm}$ compared to the Rayleigh scattering cross sections reported by Bodhaine et al. (1999).

measured $\mathrm{NO}_{2}$ and $\mathrm{CHOCHO}$ reference spectra were shifted and stretched to minimize the fit residual. The literature $\mathrm{H}_{2} \mathrm{O}$, $\mathrm{CH}_{3} \mathrm{COCHO}$, and $\mathrm{O}_{4}$ reference spectra were shifted and stretched separately.

\section{Results and discussion}

\subsection{Measured cavity loss}

The pressure response of the ACES instrument was tested by measuring $\mathrm{N}_{2}$ extinction at sample pressures between 300 and $600 \mathrm{hPa}$ in the laboratory, as shown in Fig. 3a. The measured optical extinction from Eq. (1) at $455 \mathrm{~nm}$ is plotted against the number density, $N$, determined from temperature and pressure. $I_{0}(\lambda)$ is defined to be the spectra acquired at $400 \mathrm{hPa}$. Similarly, the slope at each wavelength element can be used to determine the Rayleigh scattering cross section of $\mathrm{N}_{2}$ at that wavelength, and the results for 438 $468 \mathrm{~nm}$ are shown in Fig. 3b, with comparison to Bodhaine et al. (1999). The direct comparison of $\sigma_{\text {Rayleigh, } \mathrm{N}_{2}}$ from ACES and Bodhaine et al. (1999) shows good agreement (slope $=0.993 \pm 0.007, r^{2}=0.993$ ), indicating the pressureinsensitive performance of ACES.

Figure 4 compares the cavity loss determined from the $\mathrm{He} / \mathrm{ZA}$ and ZA/ZA methods during the SENEX 2013 research flight on 5 July 2013. He and ZA were measured 13 times during level flight legs, at pressures between $390 \mathrm{hPa}$ and $812 \mathrm{hPa}$. The calculated cavity losses, $\alpha_{\text {Cavity }}(\lambda)=(1-$ $R(\lambda)) / d$, using $\mathrm{He} / \mathrm{ZA}$ at 368 and $455 \mathrm{~nm}$, where HONO and $\mathrm{CHOCHO}$ absorption cross section are maximized, are $(3.534 \pm 0.016) \times 10^{-6}$ and $(5.551 \pm 0.017) \times 10^{-7} \mathrm{~cm}^{-1}$, respectively (all values given as mean $\pm 1 \sigma$ ). The $\alpha_{\text {cavity }}$ calculation from the ZA/ZA method, with dry zero air measurements at 390 and $812 \mathrm{hPa}$, falls within the variation of that from the He/ZA method at these two wavelengths. This comparison is additional evidence of the pressure-insensitive performance of ACES, which enables robust performance under
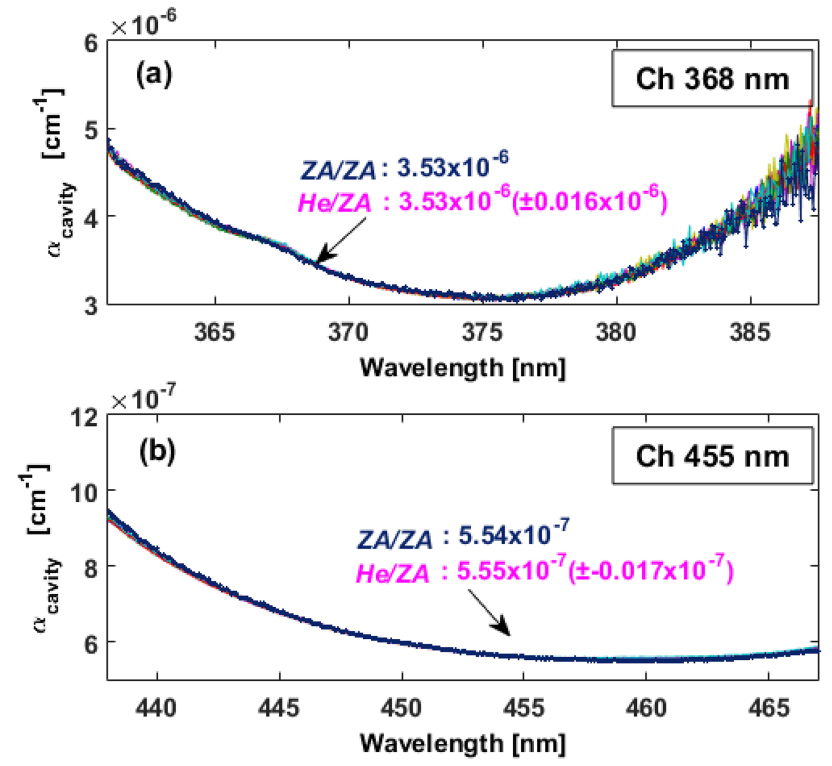

Figure 4. Cavity loss, $\alpha_{\text {cavity }}(\lambda)=(1-R(\lambda)) / d$ determined using two methods: (1) He and dry zero air (He/ZA; magenta) and (2) ZA at two different pressures (ZA/ZA; dark blue). The data are from one SENEX research flight on 5 July 2013 . The mean $( \pm 1 \sigma)$ at 368 and $455 \mathrm{~nm}$ pixels for 13 repetitions of $\mathrm{He} / \mathrm{ZA}$ during level flight legs are $(3.534 \pm 0.016) \times 10^{-6}$ and $(5.551 \pm 0.017) \times 10^{-7} \mathrm{~cm}^{-1}$, respectively, shown as magenta text with varying colored lines. The estimation at those wavelengths from ZA/ZA using 390 and $812 \mathrm{hPa}$ pressure $\left(3.53 \times 10^{-6}\right.$ and are $\left.5.54 \times 10^{-7}\right)$ is in good agreement with $\mathrm{He} / \mathrm{ZA}$.

varying external pressure. It also demonstrates that mirror reflectivity calibrations could be carried out using pressure differences alone, without the need for He gas.

Example plots showing measured intensity, cavity loss due to Rayleigh scattering, effective path length, and calculated detection limit for one pair of He/ZA measurements made 

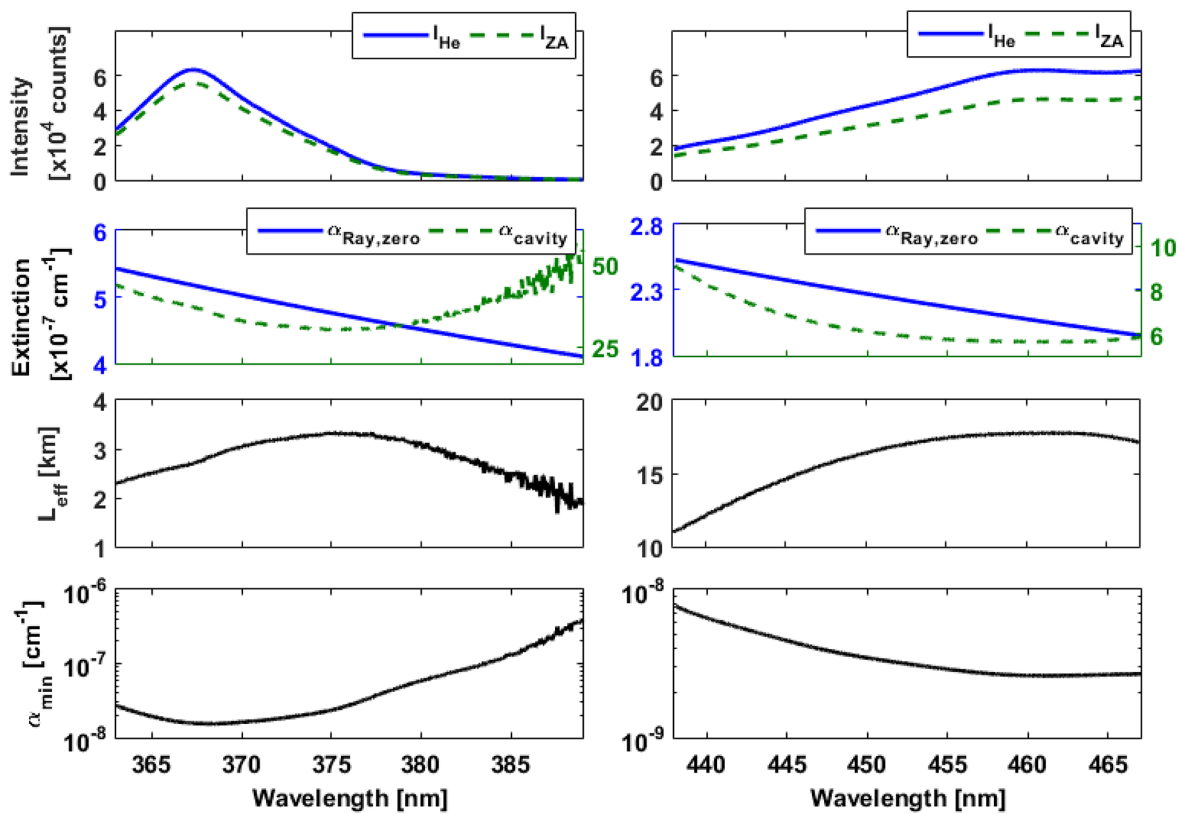

Figure 5. Results from one He/ZA measurement on 5 July 2013 with 0.5 s exposure time for Ch 368 (left panels) and Ch 455 (right panels). Figures show light intensity for $\mathrm{He}\left(I_{\mathrm{He}}\right)$ and zero air $\left(I_{\mathrm{ZA}}\right)$ measurements for raw counts at the CCD detector (incident photon counts are $16 \times$ greater due to detector gain), calculated extinction due to the Rayleigh scattering of zero air $\left(\alpha_{\text {Rayleigh, ZA }}(\lambda)\right)$, light attenuation due to cavity loss $\left(\alpha_{\text {Cavity }}(\lambda)=(1-R(\lambda)) / d\right)$, effective path length $\left(L_{\text {eff }}\right)$ at each pressure $(918.5 \mathrm{hPa}$ and $918.7 \mathrm{hPa}$ for Ch 368 and $\mathrm{Ch} 455$, respectively), and calculated detection limit $\left(\alpha_{\min }\right)$. The calculated $\alpha_{\min }$ represent the theoretical $1 \sigma$ shot noise limit for a $0.5 \mathrm{~s}$ exposure and do not include the factor of 16 gain setting. Theoretical $\alpha_{\min }$ for a $5 \mathrm{~s}$ integration are a factor of $12.6\left(16^{1 / 2} \times 10^{1 / 2}\right) 10$ low than shown (i.e., $1.2 \times 10^{-9} \mathrm{~cm}^{-1}$ at $368 \mathrm{~nm}$ in the left panel and $2.4 \times 10^{-10} \mathrm{~cm}^{-1}$ at $460 \mathrm{~nm}$ in the right panel).

on 5 July 2013 are shown in Fig. 5. For Ch 368, the signal intensity of the LED has a maximum near $368 \mathrm{~nm}$, while the mirror reflectivity is optimal near $376 \mathrm{~nm}$. Ch 455 has maximum LED intensity much closer to the best mirror reflectivity near $460 \mathrm{~nm}$ and close to the maximum glyoxal absorption feature at $455 \mathrm{~nm}$. Intensity in Fig. 5 is plotted as CCD detector counts for a $0.5 \mathrm{~s}$ exposure, and the actual photon count rate is $16 \times$ greater due to the detector gain. Rayleigh scattering loss is comparable to cavity loss for Ch 368 but is much smaller than cavity loss for $\mathrm{Ch} 455$. The effective path length, neglecting Rayleigh scattering, is $3.0 \mathrm{~km}$ at $368 \mathrm{~nm}$ and $17.8 \mathrm{~km}$ at $455 \mathrm{~nm}$. The lower panels show the minimum detectable extinction as a function of wavelength on each channel as a function of wavelength, calculated from the photon shot noise limit. See caption for further details.

\subsection{Spectral fitting}

Figures 6 and 7 show spectral fitting examples from the 3 July 2013 flight during SENEX. Figure 6 shows simultaneous retrievals of $\mathrm{NO}_{2}, \mathrm{HONO}$, and $\mathrm{O}_{4}$ with a third-order polynomial at $361-389 \mathrm{~nm}$, along with the fit result and fit residual. Figure 7 shows simultaneous retrievals of $\mathrm{NO}_{2}$, $\mathrm{CHOCHO}, \mathrm{CH}_{3} \mathrm{COCHO}, \mathrm{H}_{2} \mathrm{O}$, and $\mathrm{O}_{4}$ and with a fourthorder polynomial at $438-468 \mathrm{~nm}$, along with the total fit result and fit residual. No systematic patterns in the fit resid- ual are observed, indicating that there are no systematic errors with wavelength or missing gas-phase absorbers. The increased noise in the residuals at the edge of each fit window is due to decreased LED power (reduced photon counts) and decreased mirror reflectivity. These examples are from intercepts of a biomass burning plume with large absorption by $\mathrm{CHOCHO}$ and $\mathrm{HONO}$, as well as measurable $\mathrm{CH}_{3} \mathrm{COCHO}$.

\subsection{Precision and accuracy}

The instrumental precision and stability can be determined from optical extinction during continuous zero air measurements. Figure 8 shows an Allan deviation plot (Allan, 1966) for optical extinction at two individual pixels, calculated from $1 \mathrm{~h}$ of data acquired at constant pressure. The precision for individual pixels, rather than retrieved gas concentrations, allows the instrumental performance to be directly compared to other cavity enhanced instruments. The Allan deviation $(2 \sigma)$ follows the square root of the averaging time up to few hundred seconds. The Allan deviation in Ch 455 is roughly 4 times smaller than Ch 368 up to 1 min averaging time due to the longer effective light path length and greater LED intensity for $\mathrm{Ch} 455$. The extinction values shown in Fig. 8 represent an upper limit for the precision of trace gas retrievals because they are calculated for single pixels rather than the range of pixels used in spectral fitting. 


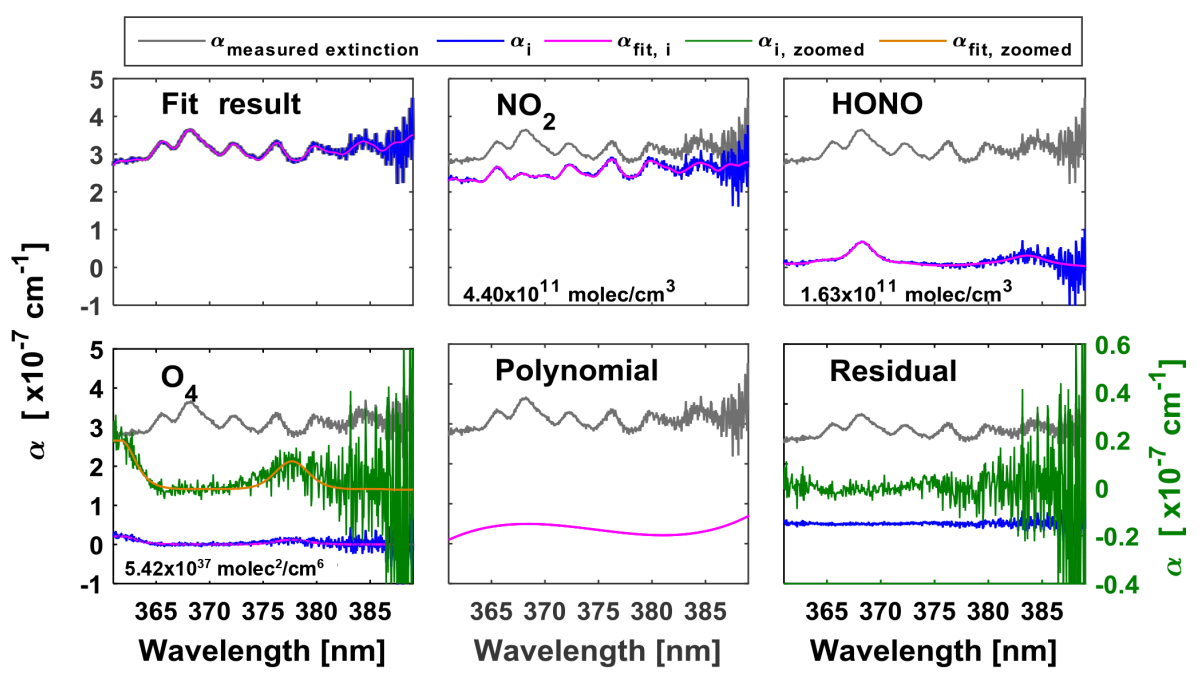

Figure 6. An example of spectral fit for one Ch 368 spectrum (10 s average) measured over an agricultural burning plume on the 3 July 2013 nighttime flight during SENEX 2013. Retrievals of $\mathrm{NO}_{2}, \mathrm{HONO}$, and $\mathrm{O}_{4}$ are shown, as well as the third-order polynomial, total fit, and residual.

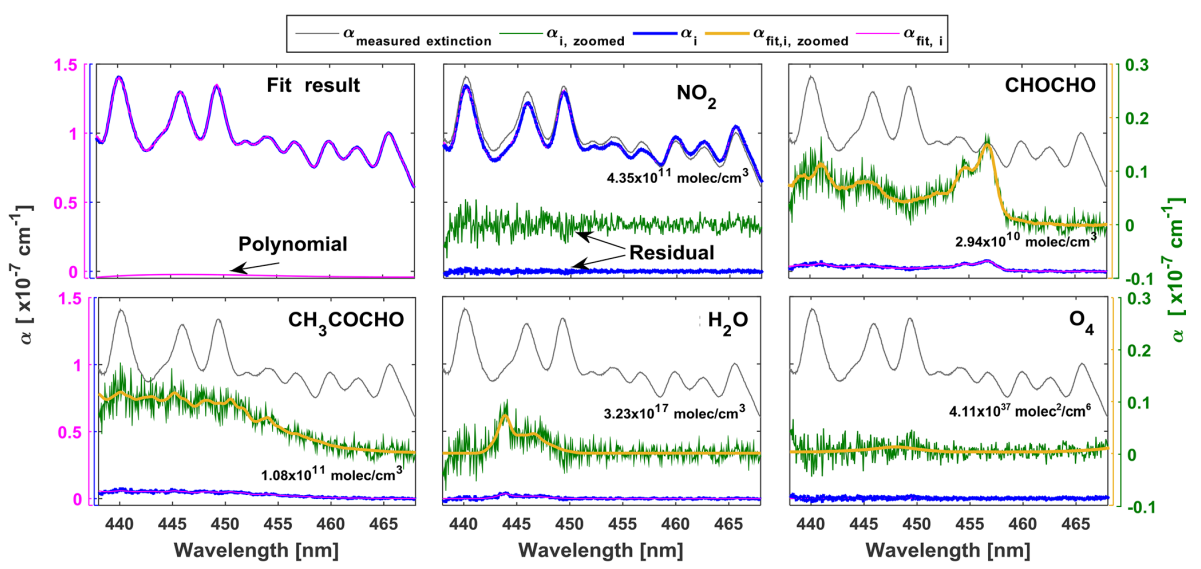

Figure 7. An example of spectral fit for one Ch 455 (10 s average) measured over an agricultural burning plume on the 3 July 2013 nighttime flight during SENEX 2013. Retrievals of $\mathrm{NO}_{2}, \mathrm{CHOCHO}, \mathrm{CH}_{3} \mathrm{COCHO}, \mathrm{H}_{2} \mathrm{O}$, and $\mathrm{O}_{4}$ are shown, as well as the third-order polynomial, total fit, and residual. Blue and pink traces are plotted against the left axis, while the expanded green and yellow traces are plotted against the right axis.

Figure 9 shows spectral retrievals of $\mathrm{NO}_{2}, \mathrm{CHOCHO}$, and HONO concentrations fit to zero air spectra acquired during ground measurements in the CARE Beijing-NCP 2014 study. The acquisition time for these data is $0.478 \mathrm{~s}$ per point with an $84 \%$ data cycle.

The instrumental precision $(2 \sigma)$ for each trace absorber is estimated from two different methods: (1) standard deviation from dry zero air retrievals and (2) fit errors derived from the DOASIS retrieval (Platt and Stutz, 2008). For both methods, the data sets for the Allan deviation analysis and regular zero air measurements during the field mission $(30 \mathrm{~s}$ injection at $5 \mathrm{~min}$ intervals) were used, as described above. The estimated precision $(2 \sigma)$ for each retrieved trace gas is summarized in Table 3. Precisions are adequate for ambient measurement of $\mathrm{CHOCHO}, \mathrm{HONO}$, and $\mathrm{NO}_{2}$, although the current precision for $\mathrm{HONO}$ is insufficient to quantify the small ambient mixing ratios reported during daytime or in low $\mathrm{NO}_{x}\left(\mathrm{NO}+\mathrm{NO}_{2}\right)$ environments (e.g., Ren et al., 2010).

The accuracy of the retrieved trace gas concentrations depends on the uncertainty of the literature reference cross sections, Rayleigh scattering cross sections, pressure, temperature, and inlet losses. The uncertainties in absorption cross sections are $4 \%$ for $\mathrm{NO}_{2}$ (Vandaele et al., 2002), $5 \%$ for CHOCHO (Volkamer et al., 2005b), $15 \%$ for $\mathrm{CH}_{3} \mathrm{COCHO}$ (Staffelbach et al., 1995), $8.7 \%$ for HONO (Stutz et al., 2000), $4 \%$ for $\mathrm{H}_{2} \mathrm{O}$ (Harder and Brault, 1997), and $10 \%$ for $\mathrm{O}_{4}$ (Greenblatt et al., 1990). The estimated uncertainty for the Rayleigh scattering cross sections of zero air is $2 \%$ 

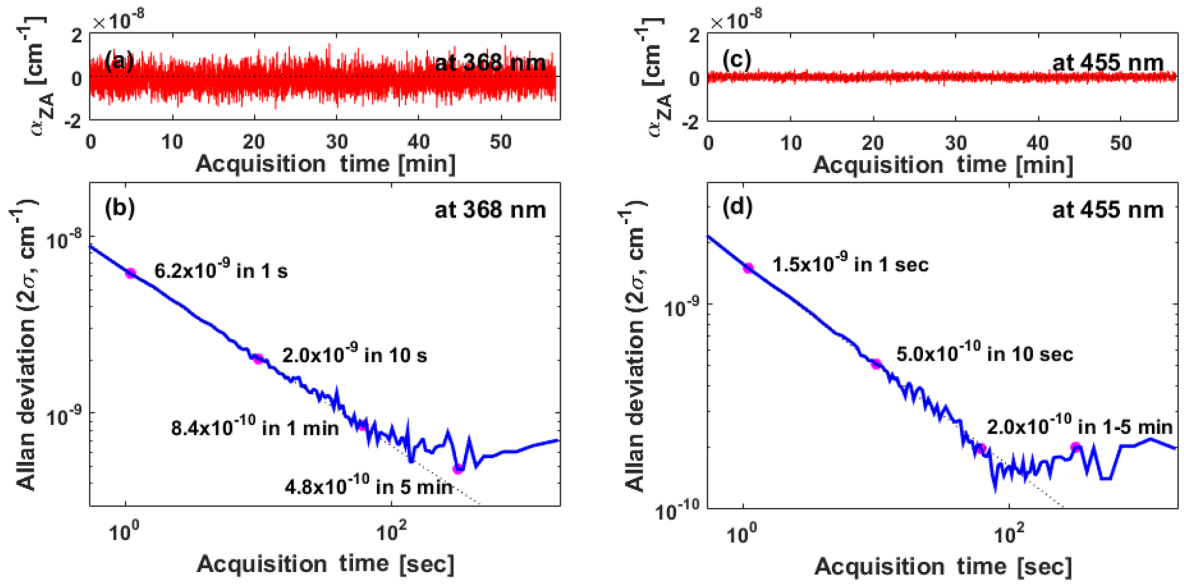

Figure 8. Allan deviation plots for single data pixels corresponding to $368 \mathrm{~nm}$ in Ch 368 (left) and $455 \mathrm{~nm}$ in Ch 455 (right). Extinction data were acquired for $1 \mathrm{~h}$ in zero air at constant pressure. The dotted line indicates the relationship expected for statistically random noise. Both channels have a $2 \sigma$ precision better than $5 \times 10^{-9} \mathrm{~cm}^{-1}$ for a $10 \mathrm{~s}$ average and are near the theoretical limits shown in Fig. 5 .
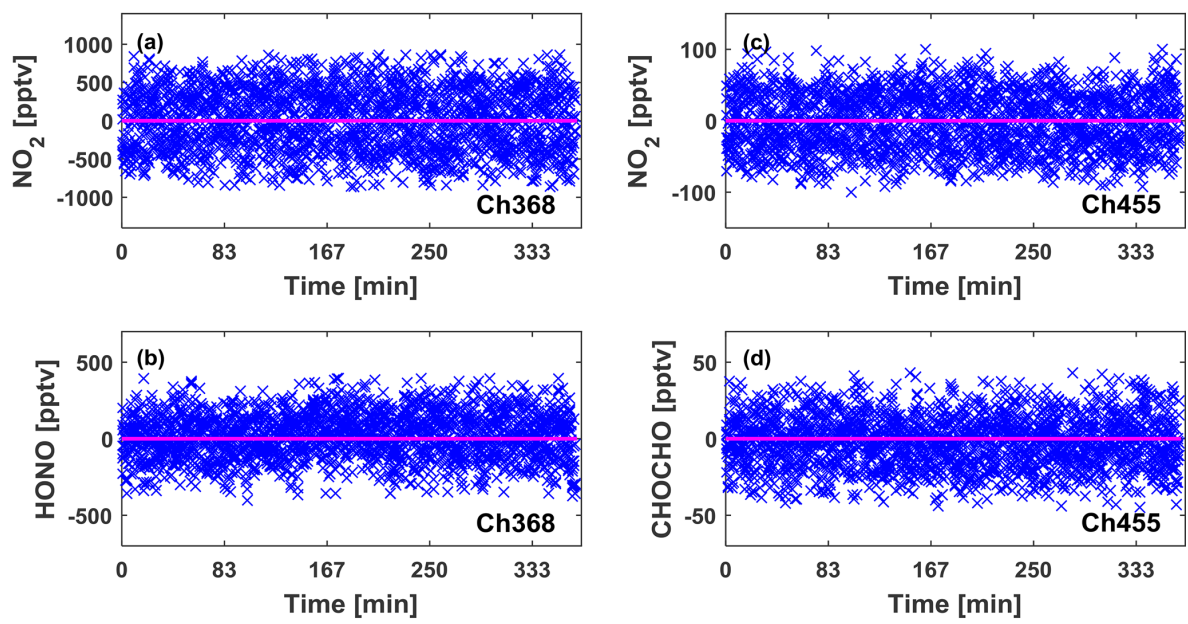

Figure 9. Spectral retrievals for $\mathrm{Ch} 368$ ( $\mathrm{NO}_{2}$ and $\mathrm{HONO}$; left panels) and $\mathrm{Ch} 455\left(\mathrm{NO}_{2}\right.$ and $\mathrm{CHOCHO}$; right panels) for zero air measurements acquired during 8-14 June 2014 for CARE Beijing-NCP 2014. Each point represents a 10 s average.

Table 3. Detection limit ( $2 \sigma)$ estimation from two different methods: (1) standard deviation of gas concentrations retrieved in zero air and (2) fit errors from DOASIS. For the laboratory data, $1 \mathrm{~h}$ of zero air measurements in the lab were analyzed. For the field data, multiple cycles of zero air measurements acquired during CARE Beijing-NCP 2014 were analyzed.

\begin{tabular}{llrrrr}
\hline Trace absorbers & \multicolumn{2}{c}{$\begin{array}{c}\text { Zero air } \\
\text { injection (pptv) }\end{array}$} & \multicolumn{2}{c}{$\begin{array}{c}\text { Fit errors } \\
\text { (pptv) }\end{array}$} \\
& & Lab & Field & Lab & Field \\
\hline Ch 455 & $\mathrm{NO}_{2}$ & 62 & 80 & 48 & $36-50$ \\
5 s average & $\mathrm{CHOCHO}^{2}$ & 30 & 34 & 30 & $22-32$ \\
Ch 368 & & & & & \\
10 s average & $\mathrm{NO}_{2}$ & 646 & 758 & 686 & $504-704$ \\
& $\mathrm{HONO}^{2}$ & 202 & 254 & 222 & $250-386$ \\
\hline
\end{tabular}

and the uncertainty for He makes a negligible contribution (Washenfelder et al., 2008). The uncertainties in pressure and temperature measurements are 0.5 and $0.7 \%$. CHOCHO loss along the inlet line is negligible, as described in Sect. 2.4 $(<0.1 \%$ for any sampling conditions used for aircraft- and ground-based sampling). HONO inlet artifacts are more difficult to characterize, since HONO may undergo loss due to adsorption or production due to heterogeneous reaction of $\mathrm{NO}_{2}$ and $\mathrm{H}_{2} \mathrm{O}$ (Finlayson-Pitts et al., 2003). The latter is of particular concern in assessing the accuracy of lowlevel HONO mixing ratios during daytime (Li et al., 2014). For this work, we have minimized HONO sampling artifacts by using a short inlet with short residence time, but we have not characterized the inlet behavior under different atmospheric conditions. The propagated errors (summed in quadrature) are $\pm 4.6 / \pm 5.0 \%$ for $\mathrm{NO}_{2}$ and $\pm 5.5 / \pm 5.8 \%$ 

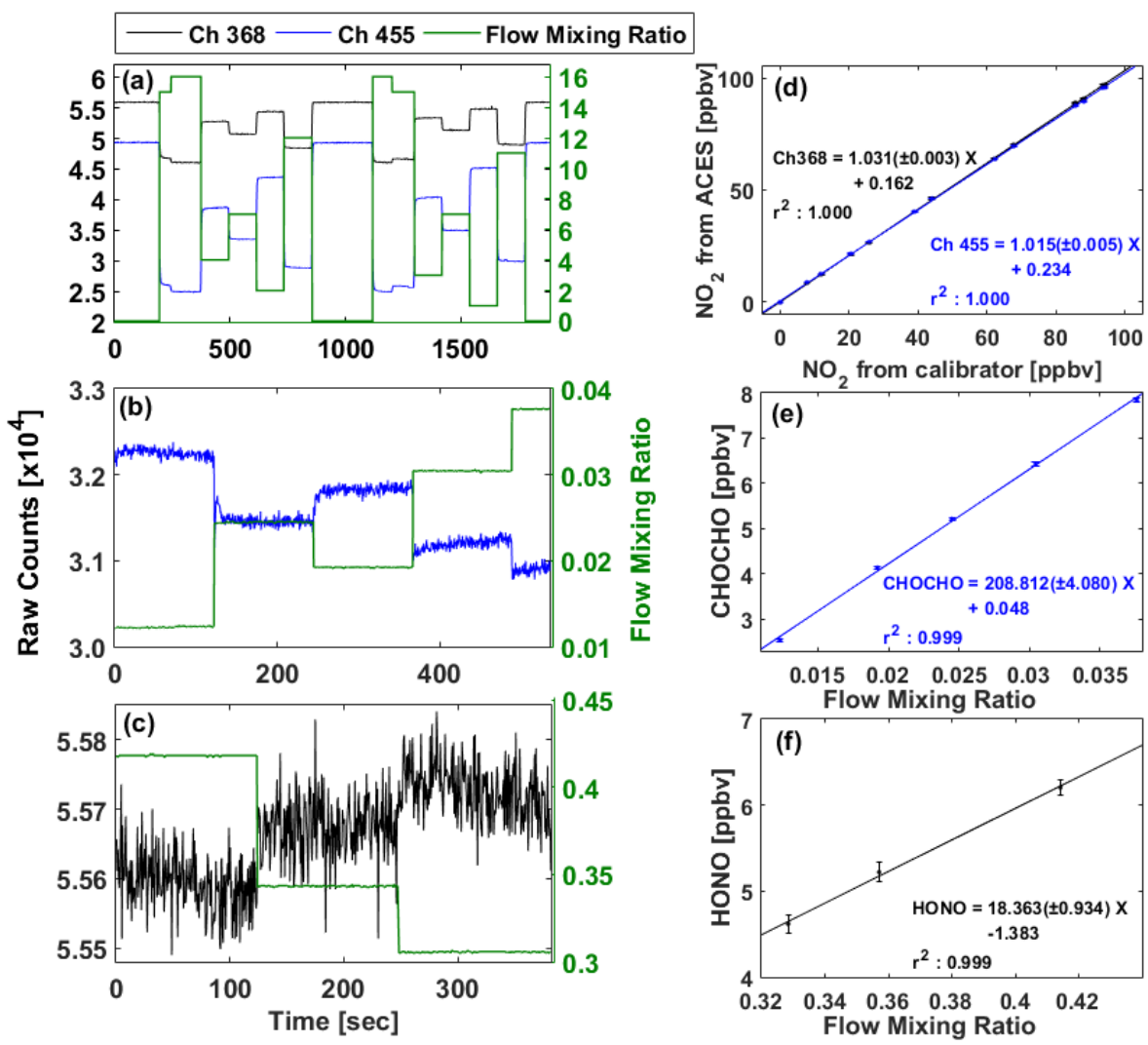

Figure 10. Standard additions of (a) $\mathrm{NO}_{2}$, (b) $\mathrm{CHOCHO}$, and (c) HONO. Left axis shows raw data counts for a single pixel at $368 \mathrm{~nm}(\mathrm{Ch}$ $368)$ and $455 \mathrm{~nm}$ (Ch 455). Right axis shows flow mixing ratio of target gas, in arbitrary units. Correlation plots for (d) $\mathrm{NO}_{2}$, (e) $\mathrm{CHOCHO}_{\text {, }}$ and (f) HONO showing the average and standard deviation for the bold points in panels (a-c). All of the comparisons are highly linear, with $r^{2}=0.999$ or 1.000 .

for $\mathrm{CHOCHO}$ using literature/measured absorption cross sections and $\pm 15.2 \%, \pm 9.0 \%, \pm 4.6 \%$, and $\pm 10.2 \%$ for $\mathrm{CH}_{3} \mathrm{COCHO}, \mathrm{HONO}$ (neglecting potential inlet artifacts), $\mathrm{H}_{2} \mathrm{O}$, and $\mathrm{O}_{4}$.

\subsection{Standard additions of trace gases}

\subsection{1 $\mathrm{NO}_{2}$}

Standard $\mathrm{NO}_{2}$ concentrations were generated using a custom calibration system (Washenfelder et al., 2011b), which generates and measures $\mathrm{O}_{3}$ using a commercial ozone monitor (49i, Thermo Fisher Scientific Inc., Waltham, MA, USA) and subsequently titrates $\mathrm{O}_{3}$ with excess $\mathrm{NO}$ (2040 parts per million $\pm 2 \%$, $\mathrm{NO}$ in $\mathrm{N}_{2}$, Scott-Marrin Inc., Riverside, CA, USA) to produce a known concentration of $\mathrm{NO}_{2}$. During SENEX 2013, we used this system daily to generate standard $\mathrm{NO}_{2}$ concentrations for validation, with typical $\mathrm{NO}_{2}$ mixing ratios between 3 and 100 parts per billion (ppbv).

Figure 10a shows one set of standard additions from the $\mathrm{NO}_{2}$ calibration system. The agreement between retrieved $\mathrm{NO}_{2}$ from ACES and the $\mathrm{NO}_{2}$ mixing ratio from the calibration system is shown in Fig. 10d. The rela- tionship is linear over the entire range $\left(r^{2}=1.000\right)$, with slopes (intercepts) of $1.031 \pm 0.003(0.16 \pm 0.14 \mathrm{ppbv})$ and $1.015 \pm 0.005$ ( $0.23 \pm 0.17 \mathrm{ppbv})$ for Ch 368 and Ch 455, respectively. The non-zero intercept is due to small concentrations of $\mathrm{NO}_{2}$ which are present in the $\mathrm{NO}$ titration gas of the calibration system (Washenfelder et al., 2011b). The deviations of the measurement from the calibration source (3.1 and $1.5 \%)$ are well within the absolute measurement accuracy of $\pm 5.0 \%$ for $\mathrm{NO}_{2}$ given in Sect. 4.2.

The $\mathrm{NO}_{2}$ standard additions demonstrate the accuracy of the ACES instrument response. In addition, we performed standard additions of HONO and CHOCHO. For these additions, we compared the ACES measurement to the calculated flow dilution because the HONO and CHOCHO concentrations were not independently determined.

\subsection{2 СHOCHO}

Figure 10b shows five additions from the $\mathrm{CHOCHO}$ source, in the range of 2-8 ppbv. Each addition was allowed to stabilize for $1 \mathrm{~min}$, and the subsequent $2 \mathrm{~min}$ of data were averaged. Figure 10e shows the average and standard deviation for these additions. The correlation coefficient $\left(r^{2}=0.999\right)$ 
indicates the linearity of the $\mathrm{CHOCHO}$ measurements from ACES and the CHOCHO calibration system. The retrieved fit errors from DOASIS were 30 parts per trillion (pptv; Table 3).

\subsubsection{HONO}

Constant HONO concentrations were generated using a calibration source based on the design by Febo et al. (1995) and Roberts et al. (2010). Briefly, humidified air mixed with $\mathrm{HCl}$ from a permeation tube passes through a sodium nitrite bed $\left(\mathrm{NaNO}_{2}\right.$ mixed with glass beads) to generate $\mathrm{HONO}$ via acid displacement. The entire system (i.e., permeation tube, water vessel, and $\mathrm{NaNO}_{2}$ bed) is temperature controlled for stable HONO generation. The output from the HONO generator may contain small amounts of $\mathrm{NO}$ and $\mathrm{NO}_{2}$.

Figure 10c shows three additions from the HONO source with different flow dilutions, in the range of 4-7 ppbv. Each addition was allowed to stabilize for $1 \mathrm{~min}$, and the subsequent $2 \mathrm{~min}$ of data were averaged. The observed delay in measurement response after a change in concentration is due to the addition source and not the inlet, which responded rapidly $(<5 \mathrm{~s})$ during aircraft sampling. Figure 10f shows the average and standard deviation of these additions, with high linearity $\left(r^{2}=0.999\right)$. The intercept value of $-1.4 \mathrm{ppbv}$ is greater than the observed precision of the measurements and may be due to variability or inaccuracy in the HONO calibration source output. The DOASIS fit errors for the $5 \mathrm{~s}$ spectra were 314 pptv (Table 3 ).

\subsection{Aircraft measurements during SENEX 2013}

The ACES instrument was deployed on the NOAA WP-3D research aircraft during the SENEX project from 1 June to 15 July 2013, with flights based out of the Smyrna/Rutherford County Airport in Smyrna, Tennessee. In addition to the ACES instrument, many instruments to characterize gas- and aerosol-phase species were deployed (see partial list in de Gouw et al., 2015), including a CRDS instrument to measure $\mathrm{NO}, \mathrm{NO}_{2}, \mathrm{NO}_{3}, \mathrm{~N}_{2} \mathrm{O}_{5}$, and $\mathrm{O}_{3}$ (Wagner et al., 2011). One goal of the field study was to understand the interactions between natural and anthropogenic emissions in the southeastern USA and to evaluate their impact on air quality and climate.

Figure 11a shows $\mathrm{CHOCHO}$ measurements acquired on 5 July 2013 during a flight that sampled high isoprene (Ozark Mountains, MO), an urban area (St. Louis, MO), and an ethanol refinery (Decatur, IL). CHOCHO mixing ratios greater than $140 \mathrm{pptv}$ were observed over St. Louis, with $\mathrm{NO}_{2}$ mixing ratios greater than 14 ppbv. Outside of the urban area, measured $\mathrm{CHOCHO}$ concentrations were 53-79 pptv (interquartile range). The time series of $\mathrm{CHOCHO}$ is shown in Fig. 11c.

Time series data for $\mathrm{NO}_{2}$ measured by ACES and CRDS are shown in Fig. 11b, with the CRDS data offset by 1 ppbv
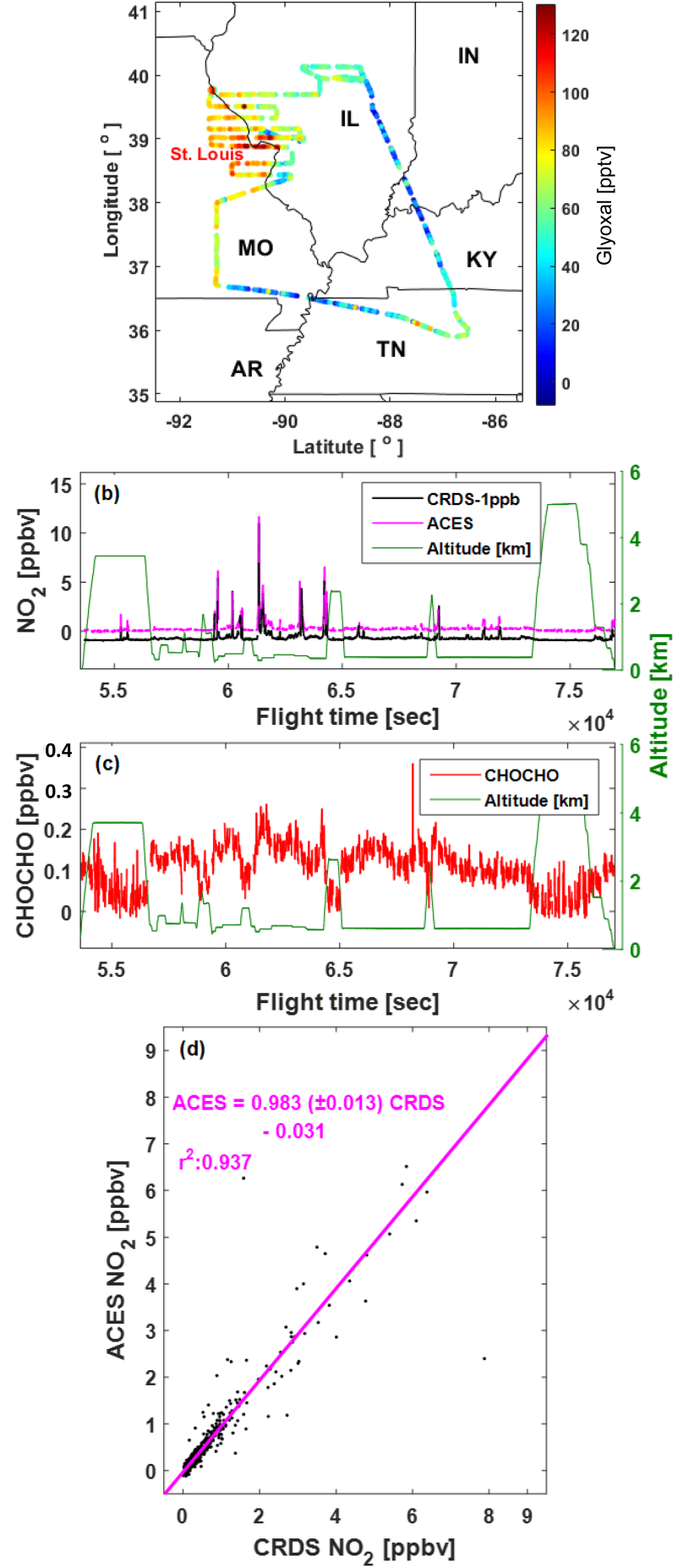

Figure 11. Data from a SENEX 2013 research flight over the central US that included areas with high isoprene and anthropogenic emissions (Ozark Mountains, MO; St. Louis, MO; Decatur, IL) (a) Flight map showing measured $\mathrm{CHOCHO}$ concentrations according to color scale. $(\mathbf{b}, \mathbf{c})$ Time series of $\mathrm{NO}_{2}$ and $\mathrm{CHOCHO}$, shown with aircraft altitude. $\mathrm{NO}_{2}$ measured by CRDS is decreased by 1 ppbv for clarity. (d) Scatter plot of ACES and CRDS $\mathrm{NO}_{2}$ data, averaged to $10 \mathrm{~s}$. The slope is $0.983 \pm 0.013$ with $r^{2}=0.937$. 

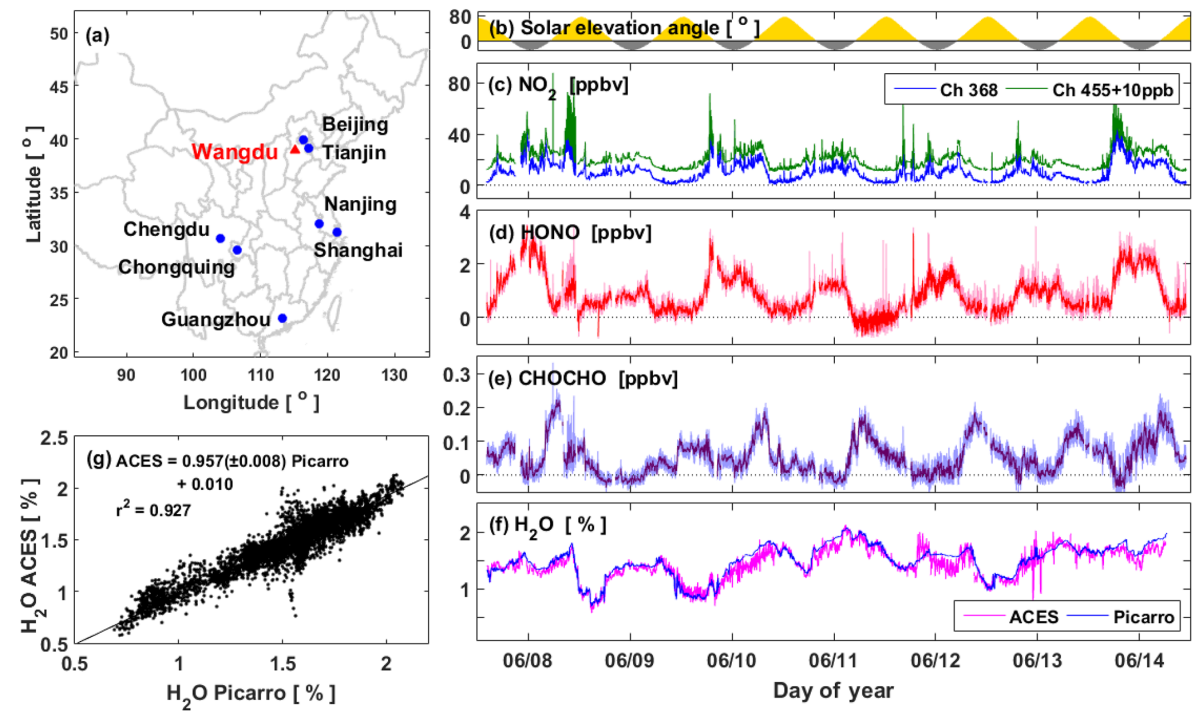

Figure 12. Data from the CARE Beijing-NCP 2014 ground site. (a) Map of region, showing ground site relative to major cities in China. Time series of (b) solar elevation angle, (c) $\mathrm{NO}_{2}$, (d) $\mathrm{HONO}$, (e) $\mathrm{CHOCHO}$, and (f) $\mathrm{H}_{2} \mathrm{O}$. $\mathrm{NO}_{2}$ measured by Ch 455 is offset by 10 ppbv for clarity. (g) Correlation plot for $\mathrm{H}_{2} \mathrm{O}$ measured by ACES and a Picarro instrument. The slope is $0.957 \pm 0.008$ with $r^{2}=0.927$.

for clarity. The CRDS instrument reported $\mathrm{NO}_{2}$ concentrations at $1 \mathrm{~s}$ time resolution with accuracy of $5 \%$ and $2 \sigma$ precision of 60 pptv (equivalent to 27 pptv for $5 \mathrm{~s}$ ) (Wild et al., 2014). A scatter plot comparing the ACES Ch 455 and CRDS $\mathrm{NO}_{2}$ data is shown in Fig. 11d, with the data averaged to $10 \mathrm{~s}$. The instruments agree well, with slope of $0.983 \pm 0.013$ and $r^{2}=0.937$, which is consistent with the uncertainty of the measurements.

$\mathrm{CH}_{3} \mathrm{COCHO}$ has been retrieved only for pyrogenic plumes during SENEX 2013, because its absorption cross section is small and contains fewer structured features than CHOCHO (see Fig. 2). As shown in Fig. 7, biomass burning plumes can represent large sources of $\mathrm{CH}_{3} \mathrm{COCHO}$, with measured mixing ratios up to $5.7 \mathrm{ppbv}$.

\subsection{Ground-based measurements during CARE Beijing-NCP 2014}

The ACES instrument was subsequently deployed during the CARE Beijing 2014 study from 2 June to 6 July 2014. Figure 12a shows a map of the North China Plain field site, which was located $198 \mathrm{~km}$ southwest of Beijing in Wangdu, Hebei Province. The overall goals of the field study focused on $\mathrm{HO}_{x}$ radical chemistry, new particle formation, and the impacts of air pollution. The scientific goals for the ACES instrument included examining the importance of anthropogenic precursors in $\mathrm{CHOCHO}$ formation and characterizing the importance of $\mathrm{CHOCHO}$ and $\mathrm{HONO}$ as radical sources.

Figure 12 shows time series for $\mathrm{NO}_{2}, \mathrm{HONO}, \mathrm{CHOCHO}$, and $\mathrm{H}_{2} \mathrm{O}$ acquired during 6 days in June 2014. $\mathrm{NO}_{2}$ and HONO concentrations peaked at night $(65$ and $3.5 \mathrm{ppbv}$, re- spectively), while glyoxal peaked during the day (240 pptv). $\mathrm{NO}_{2}$ and $\mathrm{HONO}$ mixing ratios were low during daytime and higher during nighttime, consistent with accumulation of $\mathrm{NO}_{x}$ emissions in a shallow nocturnal boundary layer, heterogeneous conversion of $\mathrm{NO}_{2}$ to $\mathrm{HONO}$ on the ground surface, and photolysis of $\mathrm{NO}_{2}$ and $\mathrm{HONO}$ during the day. In contrast, $\mathrm{CHOCHO}$ concentrations had a morning maximum, which is not typical of its diurnal pattern in other locations (Volkamer et al., 2005a; Sinreich et al., 2007; Huisman et al., 2011; Washenfelder et al., 2011a). Previous studies have shown that $\mathrm{CHOCHO}$ concentrations track the $\mathrm{OH}$ oxidation of precursors, with a maximum in the afternoon, similar to other photochemically produced species. The unusual $\mathrm{CHOCHO}$ diurnal profile at this site suggests an interaction between emissions, chemistry, and transport at the NCP site, such as a mixing of residual layer air masses with higher $\mathrm{CHOCHO}$ concentrations into the nighttime boundary layer during morning.

A number of other instruments were deployed, including a commercial instrument to measure water (G2301, Picarro Inc., Santa Clara, CA, USA). Figure 12g shows a correlation plot between the ACES Ch $455 \mathrm{H}_{2} \mathrm{O}$ retrievals and the Picarro data; 1 min data are shown due to the lower time resolution of the Picarro instrument. The agreement between the two instruments is better than $5 \%$ (slope $=0.957 \pm 0.008$, $\left.r^{2}=0.927\right)$ and demonstrates that ACES accurately retrieves $\mathrm{H}_{2} \mathrm{O}$, despite its weak cross section $\left(2.5 \times 10^{-26} \mathrm{~cm}^{2}\right.$ at the instrument resolution, see Fig. 2). 


\section{Conclusions}

The ACES instrument is engineered to provide robust, highly sensitive, and fast time-response measurements under aircraft sampling conditions. The design includes a temperature-controlled, custom-designed optical system with electronic LED on/off modulation and low-noise CCD cooled to $-50{ }^{\circ} \mathrm{C}$. The instrument is also appropriate for field campaigns on other platforms, as well as for laboratory studies of trace gases and aerosols.

At $438-468 \mathrm{~nm}$, the demonstrated precision $(2 \sigma)$ for field measurements of $\mathrm{CHOCHO}$ and $\mathrm{NO}_{2}$ is 34 and 80 pptv in 5 $\mathrm{s}$, respectively. The calculated accuracies for these measurements are 5.8 and $5.0 \%$, which is consistent with standard additions and comparison to an independent $\mathrm{NO}_{2}$ measurement.

At $361-389 \mathrm{~nm}$, the demonstrated precision for field measurements of $\mathrm{HONO}$ and $\mathrm{NO}_{2}$ is 760 and $250 \mathrm{pptv}$ in $10 \mathrm{~s}$, respectively. The calculated accuracies for these measurements are 9.0 and $4.6 \%$, which is consistent with standard additions and comparison to an independent $\mathrm{NO}_{2}$ measurement. Due to its lower precision, the ACES HONO measurement in its current configuration is better suited to ground-based sampling (e.g., 300 pptv in $1 \mathrm{~min}, 100 \mathrm{pptv}$ in $10 \mathrm{~min}, 40 \mathrm{pptv}$ in $1 \mathrm{~h}$, with long-term drift eliminated by zeroing) and laboratory kinetic studies. In the future, higher sensitivity could be achieved through higher-quality cavity mirrors with lower absorption and scattering losses in the coating or different UV light sources that better match HONO's strong absorption bands.

In addition to the target analytes, $\mathrm{CH}_{3} \mathrm{COCHO}$ can be retrieved from fire plumes, and other high-concentration environments. ACES $\mathrm{H}_{2} \mathrm{O}$ measurements show good agreement with independent data acquired at the CARE Beijing-NCP 2014 site.

Acknowledgements. We thank the NOAA WP-3D flight support crew and science team for the successful SENEX 2013 mission. We thank Taylor Brownlee for characterization of LED sources. The authors acknowledge contribution from the CARE BeijingNCP 2014 team and funding from the National Natural Science Foundation of China (21190052), Strategic Priority Research Program of the Chinese Academy of Sciences (XDB05010500), and US National Science Foundation (AGS-1405805). K.-E. Min acknowledges a postdoctoral fellowship from the Cooperative Institute for Research in Environmental Sciences at the University of Colorado. This work was supported in part by NOAA's Atmospheric Chemistry, Climate and Carbon Cycle (AC4) program.

Edited by: M. D. Andrés Hernández

\section{References}

Alicke, B., Platt, U., and Stutz, J.: Impact of nitrous acid photolysis on the total hydroxyl radical budget during the Lim- itation of Oxidant Production/Pianura Padana Produzione di Ozono study in Milan, J. Geophys. Res.-Atmos., 107, 8196, doi:10.1029/2000JD000075, 2002.

Allan, D. W.: Statistics of atomic frequency standards, Pr. Inst. Electr. Elect., 54, 221-230, 1966.

Appel, B. R., Winer, A. M., Tokiwa, Y., and Biermann, H. W.: Comparison of atmospheric nitrous acid measurements by annular denuder and differential optical absorption systems, Atmos. Environ., 24, 611-616, 1990.

Axson, J. L., Washenfelder, R. A., Kahan, T. F., Young, C. J., Vaida, V., and Brown, S. S.: Absolute ozone absorption cross section in the Huggins Chappuis minimum $(350-470 \mathrm{~nm})$ at 296 K, Atmos. Chem. Phys., 11, 11581-11590, doi:10.5194/acp11-11581-2011, 2011.

Baidar, S., Oetjen, H., Coburn, S., Dix, B., Ortega, I., Sinreich, R., and Volkamer, R.: The CU Airborne MAX-DOAS instrument: vertical profiling of aerosol extinction and trace gases, Atmos. Meas. Tech., 6, 719-739, doi:10.5194/amt-6-719-2013, 2013.

Ball, S. M., Langridge, J. M., and Jones, R. L.: Broadband cavity enhanced absorption spectroscopy using light emitting diodes, Chem. Phys. Lett., 398, 68-74, 2004.

Barney, W. S., Wingen, L. M., Lakin, M. J., Brauers, T., Stutz, J., and Finlayson-Pitts, B. J.: Infrared absorption cross-section measurements for nitrous acid (HONO) at room temperature, J. Phys. Chem. A, 104, 1692-1699, 2000.

Benton, A. K., Langridge, J. M., Ball, S. M., Bloss, W. J., Dall'Osto, M., Nemitz, E., Harrison, R. M., and Jones, R. L.: Night-time chemistry above London: measurements of $\mathrm{NO}_{3}$ and $\mathrm{N}_{2} \mathrm{O}_{5}$ from the BT Tower, Atmos. Chem. Phys., 10, 9781-9795, doi:10.5194/acp-10-9781-2010, 2010.

Bodhaine, B. A., Wood, N. B., Dutton, E. G., and Slusser, J. R.: On Rayleigh optical depth calculations, J. Atmos. Ocean. Tech., 16, 1854-1861, 1999.

Chen, J. and Venables, D. S.: A broadband optical cavity spectrometer for measuring weak near-ultraviolet absorption spectra of gases, Atmos. Meas. Tech., 4, 425-436, doi:10.5194/amt-4-4252011, 2011.

Coburn, S., Ortega, I., Thalman, R., Blomquist, B., Fairall, C. W., and Volkamer, R.: Measurements of diurnal variations and eddy covariance (EC) fluxes of glyoxal in the tropical marine boundary layer: description of the Fast LED-CE-DOAS instrument, Atmos. Meas. Tech., 7, 3579-3595, doi:10.5194/amt-7-3579-2014, 2014.

de Gouw, J. A., McKeen, S. A., Aikin, K. C., Brock, C. A., Brown, S. S., Gilman, J. B., Graus, M., Hanisco, T., Holloway, J. S., Kaiser, J., Keutsch, F. N., Lerner, B. M., Liao, J., Markovic, M. Z., Middlebrook, A. M., Min, K.-E., Neuman, J. A., Nowak, J. B., Peischl, J., Pollack, I. B., Roberts, J. M., Ryerson, T. B., Trainer, M., Veres, P. R., Warneke, C., Welti, A., and Wolfe, G. M.: Airborne measurements of the atmospheric emissions from a fuel ethanol refinery, J. Geophys. Res., 120, 4385-4397, doi:10.1002/2015/2015jd023138, 2015.

Dibb, J. E., Arsenault, M., Peterson, M. C., and Honrath, R. E.: Fast nitrogen oxide photochemistry in Summit, Greenland snow, Atmos. Environ., 36, 2501-2511, 2002.

Febo, A., Perrino, C., Gherardi, M., and Sparapani, R.: Evaluation of a high-purity and high-stability continuous generation system for nitrous acid, Environ. Sci. Technol., 29, 2390-2395, 1995. 
Fiedler, S. E., Hese, A., and Ruth, A. A.: Incoherent broad-band cavity-enhanced absorption spectroscopy, Chem. Phys. Lett., 371, 284-294, 2003.

Finlayson-Pitts, B. J., Wingen, L. M., Sumner, A. L., Syomin, D., and Ramazan, K. A.: The heterogeneous hydrolysis of $\mathrm{NO}_{2}$ in laboratory systems and in outdoor and indoor atmospheres: An integrated mechanism, Phys. Chem. Chem. Phys., 5, 223-242, doi:10.1039/b208564j, 2003.

Fu, T. M., Jacob, D. J., Wittrock, F., Burrows, J. P., Vrekoussis, M., and Henze, D. K.: Global budgets of atmospheric glyoxal and methylglyoxal, and implications for formation of secondary organic aerosols, J. Geophys. Res., 113, D15303, doi:10.1029/2007JD009505, 2008.

Fuchs, H., Dube, W. P., Lerner, B. M., Wagner, N. L., Williams, E. J., and Brown, S. S.: A sensitive and versatile detector for atmospheric $\mathrm{NO}_{2}$ and $\mathrm{NO}_{x}$ based on blue diode laser davity ring-down spectroscopy, Environ. Sci. Technol., 43, 7831-7836, 2009.

Gherman, T., Venables, D. S., Vaughan, S., Orphal, J., and Ruth, A. A.: Incoherent broadband cavity-enhanced absorption spectroscopy in the near-ultraviolet: Application to $\mathrm{HONO}$ and $\mathrm{NO}_{2}$, Environ. Sci. Technol., 42, 890-895, 2008.

Greenblatt, G. D., Orlando, J. J., Burkholder, J. B., and Ravishankara, A. R.: Absorption measurements of oxygen between $330 \mathrm{~nm}$ and $1140 \mathrm{~nm}$, J. Geophys. Res., 95, 18577-18582, 1990.

Grosjean, D., Grosjean, E., and Moreira, L. F. R.: Speciated ambient carbonyls in Rio de Janeiro, Brazil, Environ. Sci. Technol., 36, 1389-1395, 2002.

Harder, J. W. and Brault, J. W.: Atmospheric measurements of water vapor in the $442 \mathrm{~nm}$ region, J. Geophys. Res.-Atmos., 102, 62456252, 1997.

Hastings, W. P., Koehler, C. A., Bailey, E. L., and De Haan, D. O.: Secondary organic aerosol formation by glyoxal hydration and oligomer formation: Humidity effects and equilibrium shifts during analysis, Environ. Sci. Technol., 39, 8728-8735, 2005.

Hendrick, F., Müller, J.-F., Clémer, K., Wang, P., De Mazière, M., Fayt, C., Gielen, C., Hermans, C., Ma, J. Z., Pinardi, G., Stavrakou, T., Vlemmix, T., and Van Roozendael, M.: Four years of ground-based MAX-DOAS observations of HONO and $\mathrm{NO}_{2}$ in the Beijing area, Atmos. Chem. Phys., 14, 765-781, doi:10.5194/acp-14-765-2014, 2014.

Huisman, A. J., Hottle, J. R., Coens, K. L., DiGangi, J. P., Galloway, M. M., Kammrath, A., and Keutsch, F. N.: Laser-induced phosphorescence for the in situ detection of glyoxal at part per trillion mixing ratios, Anal. Chem., 80, 5884-5891, 2008.

Huisman, A. J., Hottle, J. R., Galloway, M. M., DiGangi, J. P., Coens, K. L., Choi, W., Faloona, I. C., Gilman, J. B., Kuster, W. C., de Gouw, J., Bouvier-Brown, N. C., Goldstein, A. H., LaFranchi, B. W., Cohen, R. C., Wolfe, G. M., Thornton, J. A., Docherty, K. S., Farmer, D. K., Cubison, M. J., Jimenez, J. L., Mao, J., Brune, W. H., and Keutsch, F. N.: Photochemical modeling of glyoxal at a rural site: observations and analysis from BEARPEX 2007, Atmos. Chem. Phys., 11, 8883-8897, doi:10.5194/acp-11-88832011, 2011.

Jang, M. S., Czoschke, N. M., Lee, S., and Kamens, R. M.: Heterogeneous atmospheric aerosol production by acid-catalyzed particle-phase reactions, Science, 298, 814-817, 2002.

Kahan, T. F., Washenfelder, R. A., Vaida, V., and Brown, S. S.: Cavity-enhanced measurements of hydrogen peroxide absorption cross sections from 353 to 410 nm, J. Phys. Chem. A, 116, 59415947, 2012.

Kalberer, M., Paulsen, D., Sax, M., Steinbacher, M., Dommen, J., Prevot, A. S. H., Fisseha, R., Weingartner, E., Frankevich, V., Zenobi, R., and Baltensperger, U.: Identification of polymers as major components of atmospheric organic aerosols, Science, 303, 1659-1662, 2004.

Kennedy, O. J., Ouyang, B., Langridge, J. M., Daniels, M. J. S., Bauguitte, S., Freshwater, R., McLeod, M. W., Ironmonger, C., Sendall, J., Norris, O., Nightingale, R., Ball, S. M., and Jones, R. L.: An aircraft based three channel broadband cavity enhanced absorption spectrometer for simultaneous measurements of $\mathrm{NO}_{3}, \mathrm{~N}_{2} \mathrm{O}_{5}$ and $\mathrm{NO}_{2}$, Atmos. Meas. Tech., 4, 1759-1776, doi:10.5194/amt-4-1759-2011, 2011.

Kleffmann, J., Lorzer, J. C., Wiesen, P., Kern, C., Trick, S., Volkamer, R., Rodenas, M., and Wirtz, K.: Intercomparison of the DOAS and LOPAP techniques for the detection of nitrous acid (HONO), Atmos. Environ., 40, 3640-3652, 2006.

Kraus, S. G.: DOASIS: A Framework Design for DOAS, Dissertation, University of Mannheim, Mannheim, Germany, 2006.

Kroll, J. H., Ng, N. L., Murphy, S. M., Varutbangkul, V., Flagan, R. C., and Seinfeld, J. H.: Chamber studies of secondary organic aerosol growth by reactive uptake of simple carbonyl compounds, J. Geophys. Res., 110, D23207, doi:10.1029/2005JD006004, 2005.

Langridge, J. M., Ball, S. M., and Jones, R. L.: A compact broadband cavity enhanced absorption spectrometer for detection of atmospheric $\mathrm{NO}_{2}$ using light emitting diodes, Analyst, 131, 916922, 2006.

Langridge, J. M., Gustafsson, R. J., Griffiths, P. T., Cox, R. A., Lambert, R. M., and Jones, R. L.: Solar driven nitrous acid formation on building material surfaces containing titanium dioxide: A concern for air quality in urban areas?, Atmos. Environ., 43, 51285131, doi:10.1016/j.atmosenv.2009.06.046, 2009.

Lee, B. H., Santoni, G. W., Wood, E. C., Herndon, S. C., MiakeLye, R. C., Zahniser, M. S., Wofsy, S. C., and Munger, J. W.: Measurements of nitrous acid in commercial aircraft exhaust at the alternative aviation fuel experiment, Environ. Sci. Technol., 45, 7648-7654, 2011.

Li, X., Rohrer, F., Hofzumahaus, A., Brauers, T., Haseler, R., Bohn, B., Broch, S., Fuchs, H., Gomm, S., Holland, F., Jager, J., Kaiser, J., Keutsch, F. N., Lohse, I., Lu, K. D., Tillmann, R., Wegener, R., Wolfe, G. M., Mentel, T. F., Kiendler-Scharr, A., and Wahner, A.: Missing gas phase source of HONO inferred from zeppelin measurements in the troposphere, Science, 344, 292-296, 10.1126/science.1248999, 2014.

Li, Y. Q., Schwab, J. J., and Demerjian, K. L.: Fast time response measurements of gaseous nitrous acid using a tunable diode laser absorption spectrometer: HONO emission source from vehicle exhausts, Geophys. Res. Lett., 35, L04803, doi:10.1029/2007GL031218, 2008.

Liggio, J., Li, S. M., and Mclaren, R.: Reactive uptake of glyoxal by particulate matter, J. Geophys. Res., 110, D10304, doi:10.1029/2004JD005113, 2005.

Lin, G., Penner, J. E., Sillman, S., Taraborrelli, D., and Lelieveld, J.: Global modeling of SOA formation from dicarbonyls, epoxides, organic nitrates and peroxides, Atmos. Chem. Phys., 12, 47434774, doi:10.5194/acp-12-4743-2012, 2012. 
MacDonald, S. M., Oetjen, H., Mahajan, A. S., Whalley, L. K., Edwards, P. M., Heard, D. E., Jones, C. E., and Plane, J. M. C.: DOAS measurements of formaldehyde and glyoxal above a south-east Asian tropical rainforest, Atmos. Chem. Phys., 12, 5949-5962, doi:10.5194/acp-12-5949-2012, 2012.

Mahajan, A. S., Prados-Roman, C., Hay, T. D., Lampel, J., Pohler, D., Grossmann, K., Tschritter, J., Friess, U., Platt, U., Johnston, P., Kreher, K., Wittrock, F., Burrows, J. P., Plane, J. M. C., and Saiz-Lopez, A.: Glyoxal observations in the global marine boundary layer, J. Geophys. Res.-Atmos., 119, 6160-6169, 2014

Munger, J. W., Jacob, D. J., Daube, B. C., Horowitz, L. W., Keene, W. C., and Heikes, B. G.: Formaldehyde, glyoxal, and methylglyoxal in air and cloudwater at a rural mountain site in Central Virginia, J. Geophys. Res.-Atmos., 100, 9325-9333, 1995.

Nakao, S., Liu, Y., Tang, P., Chen, C.-L., Zhang, J., and Cocker III, D. R.: Chamber studies of SOA formation from aromatic hydrocarbons: observation of limited glyoxal uptake, Atmos. Chem. Phys., 12, 3927-3937, doi:10.5194/acp-12-3927-2012, 2012.

Osthoff, H. D., Brown, S. S., Ryerson, T. B., Fortin, T. J., Lerner, B. M., Williams, E. J., Pettersson, A., Baynard, T., Dube, W. P., Ciciora, S. J., and Ravishankara, A. R.: Measurement of atmospheric $\mathrm{NO}_{2}$ by pulsed cavity ring-down spectroscopy, J. Geophys. Res., 111, D12305, doi:10.1029/2005JD006942, 2006.

Platt, U. and Stutz, J.: Differential Optical Absorption Spectroscopy, Springer-Verlag Berlin Heidelberg, Germany, 598 pp., 2008.

Platt, U., Perner, D., Harris, G. W., Winer, A. M., and Pitts, J. N.: Observations of nitrous acid in an urban atmosphere by differential optical absorption, Nature, 285, 312-314, 1980.

Ren, X., Gao, H., Zhou, X., Crounse, J. D., Wennberg, P. O., Browne, E. C., LaFranchi, B. W., Cohen, R. C., McKay, M., Goldstein, A. H., and Mao, J.: Measurement of atmospheric nitrous acid at Bodgett Forest during BEARPEX2007, Atmos. Chem. Phys., 10, 6283-6294, doi:10.5194/acp-10-6283-2010, 2010.

Roberts, J. M., Veres, P., Warneke, C., Neuman, J. A., Washenfelder, R. A., Brown, S. S., Baasandorj, M., Burkholder, J. B., Burling, I. R., Johnson, T. J., Yokelson, R. J., and de Gouw, J.: Measurement of HONO, HNCO, and other inorganic acids by negative-ion proton-transfer chemical-ionization mass spectrometry (NI-PT-CIMS): application to biomass burning emissions, Atmos. Meas. Tech., 3, 981-990, doi:10.5194/amt-3-981-2010, 2010.

Sansonetti, C. J., Salit, M. L., and Reader, J.: Wavelengths of spectral lines in mercury pencil lamps, Appl. Optics, 35, 74-77, 1996.

Shardanand, S. and Rao, A. D. P.: Absolute Rayleigh scattering cross sections of gases and freons of stratospheric interest in the visible and ultraviolet regions, NASA Technical Note, 1977.

Sinreich, R., Volkamer, R., Filsinger, F., Frieß, U., Kern, C., Platt, U., Sebastián, O., and Wagner, T.: MAX-DOAS detection of glyoxal during ICARTT 2004, Atmos. Chem. Phys., 7, 1293-1303, doi:10.5194/acp-7-1293-2007, 2007.

Sinreich, R., Coburn, S., Dix, B., and Volkamer, R.: Ship-based detection of glyoxal over the remote tropical Pacific Ocean, Atmos. Chem. Phys., 10, 11359-11371, doi:10.5194/acp-1011359-2010, 2010.
Sneep, M., and Ubachs, W.: Direct measurement of the Rayleigh scattering cross section in various gases, J. Quant. Spectrosc. Ra., 92, 293-310, 2005.

Staffelbach, T. A., Orlando, J. J., Tyndall, G. S., and Calvert, J. G.: The UV-visible absorption spectrum and photolysis quantum yields of methylglyoxal, J. Geophys. Res., 100, 14189-14198, 1995.

Stutz, J., Kim, E. S., Platt, U., Bruno, P., Perrino, C., and Febo, A.: UV-visible absorption cross sections of nitrous acid, J. Geophys. Res., 105, 14585-14592, 2000.

Stutz, J., Oh, H. J., Whitlow, S. I., Anderson, C., Dibbb, J. E., Flynn, J. H., Rappengluck, B., and Lefer, B.: Simultaneous DOAS and mist-chamber IC measurements of HONO in Houston, TX, Atmos. Environ., 44, 4090-4098, 2010.

Su, H., Cheng, Y. F., Shao, M., Gao, D. F., Yu, Z. Y., Zeng, L. M., Slanina, J., Zhang, Y. H., and Wiedensohler, A.: Nitrous acid (HONO) and its daytime sources at a rural site during the 2004 PRIDE-PRD experiment in China, J. Geophys. Res.Atmos., 113, D14312, doi:10.1029/2007jd009060, 2008.

Thalman, R. and Volkamer, R.: Inherent calibration of a blue LED-CE-DOAS instrument to measure iodine oxide, glyoxal, methyl glyoxal, nitrogen dioxide, water vapour and aerosol extinction in open cavity mode, Atmos. Meas. Tech., 3, 1797-1814, doi:10.5194/amt-3-1797-2010, 2010.

Thalman, R., Zarzana, K. J., Tolbert, M. A., and Volkamer, R.: Rayleigh scattering cross-section measurements of nitrogen, argon, oxygen and air, J. Quant. Spectrosc. Ra., 147, 171-177, 2014.

Thalman, R., Baeza-Romero, M. T., Ball, S. M., Borrás, E., Daniels, M. J. S., Goodall, I. C. A., Henry, S. B., Karl, T., Keutsch, F. N., Kim, S., Mak, J., Monks, P. S., Muñoz, A., Orlando, J., Peppe, S., Rickard, A. R., Ródenas, M., Sánchez, P., Seco, R., Su, L., Tyndall, G., Vázquez, M., Vera, T., Waxman, E., and Volkamer, R.: Instrument intercomparison of glyoxal, methyl glyoxal and $\mathrm{NO}_{2}$ under simulated atmospheric conditions, Atmos. Meas. Tech., 8, 1835-1862, doi:10.5194/amt-8-1835-2015, 2015.

Thompson, J. E. and Spangler, H. D.: Tungsten source integrated cavity output spectroscopy for the determination of ambient atmospheric extinction coefficient, Appl. Optics, 45, 2465-2473, 2006.

Vandaele, A. C., Hermans, C., Fally, S., Carleer, M., Colin, R., Merienne, M. F., Jenouvrier, A., and Coquart, B.: High-resolution Fourier transform measurement of the $\mathrm{NO}_{2}$ visible and nearinfrared absorption cross sections: Temperature and pressure effects, J. Geophys. Res., 107, 4348, doi:10.1029/2001JD000971, 2002.

VandenBoer, T. C., Brown, S. S., Murphy, J. G., Keene, W. C., Young, C. J., Pszenny, A. A. P., Kim, S., Warneke, C., de Gouw, J. A., Maben, J. R., Wagner, N. L., Riedel, T. P., Thornton, J. A., Wolfe, D. E., Dube, W. P., Ozturk, F., Brock, C. A., Grossberg, N., Lefer, B., Lerner, B., Middlebrook, A. M., and Roberts, J. M.: Understanding the role of the ground surface in HONO vertical structure: High resolution vertical profiles during NACHTT-11, J. Geophys. Res., 118, 10155-10171, 2013.

Varma, R. M., Ball, S. M., Brauers, T., Dorn, H.-P., Heitmann, U., Jones, R. L., Platt, U., Pöhler, D., Ruth, A. A., Shillings, A. J. L., Thieser, J., Wahner, A., and Venables, D. S.: Light extinction by secondary organic aerosol: an intercomparison of three broad- 
band cavity spectrometers, Atmos. Meas. Tech., 6, 3115-3130, doi:10.5194/amt-6-3115-2013, 2013.

Vaughan, S., Gherman, T., Ruth, A. A., and Orphal, J.: Incoherent broad-band cavity-enhanced absorption spectroscopy of the marine boundary layer species $\mathrm{I}_{2}, \mathrm{IO}$ and OIO, Phys. Chem. Chem. Phys., 10, 4471-4477, 2008.

Venables, D. S., Gherman, T., Orphal, J., Wenger, J. C., and Ruth, A. A.: High sensitivity in situ monitoring of $\mathrm{NO}_{3}$ in an atmospheric simulation chamber using incoherent broadband cavity-enhanced absorption spectroscopy, Environ. Sci. Technol., 40, 6758-6763, 2006.

Veres, P. R., Roberts, J. M., Wild, R. J., Edwards, P. M., Brown, S. S., Bates, T. S., Quinn, P. K., Johnson, J. E., Zamora, R. J., and de Gouw, J.: Peroxynitric acid $\left(\mathrm{HO}_{2} \mathrm{NO}_{2}\right)$ measurements during the UBWOS 2013 and 2014 studies using iodide ion chemical ionization mass spectrometry, Atmos. Chem. Phys., 15, 81018114, doi:10.5194/acp-15-8101-2015, 2015.

Volkamer, R., Molina, L. T., Molina, M. J., Shirley, T., and Brune, W. H.: DOAS measurement of glyoxal as an indicator for fast VOC chemistry in urban air, Geophys. Res. Lett., 32, L08806, doi:10.1029/2005GL022616, 2005a.

Volkamer, R., Spietz, P., Burrows, J., and Platt, U.: High-resolution absorption cross-section of glyoxal in the UV-vis and IR spectral ranges, J. Photoch. Photobio. A, 172, 35-46, 2005 b.

Volkamer, R., Martini, F. S., Molina, L. T., Salcedo, D., Jimenez, J. L., and Molina, M. J.: A missing sink for gas-phase glyoxal in Mexico City: Formation of secondary organic aerosol, Geophys. Res. Lett., 34, L19807, doi:10.1029/2007GL030752, 2007.

Volkamer, R., Baidar, S., Campos, T. L., Coburn, S., DiGangi, J. P., Dix, B., Eloranta, E. W., Koenig, T. K., Morley, B., Ortega, I., Pierce, B. R., Reeves, M., Sinreich, R., Wang, S., Zondlo, M. A., and Romashkin, P. A.: Aircraft measurements of BrO, IO, glyoxal, $\mathrm{NO}_{2}, \mathrm{H}_{2} \mathrm{O}, \mathrm{O}_{2}-\mathrm{O}_{2}$ and aerosol extinction profiles in the tropics: comparison with aircraft-/ship-based in situ and lidar measurements, Atmos. Meas. Tech., 8, 2121-2148, doi:10.5194/amt-8-2121-2015, 2015.

Wagner, N. L., Dubé, W. P., Washenfelder, R. A., Young, C. J., Pollack, I. B., Ryerson, T. B., and Brown, S. S.: Diode laser-based cavity ring-down instrument for $\mathrm{NO}_{3}, \mathrm{~N}_{2} \mathrm{O}_{5}, \mathrm{NO}$, $\mathrm{NO}_{2}$ and $\mathrm{O}_{3}$ from aircraft, Atmos. Meas. Tech., 4, 1227-1240, doi:10.5194/amt-4-1227-2011, 2011.

Wang, L. M. and Zhang, J. S.: Detection of nitrous acid by cavity ring down spectroscopy, Environ. Sci. Technol., 34, 4221-4227, 2000.

Washenfelder, R. A., Langford, A. O., Fuchs, H., and Brown, S. S.: Measurement of glyoxal using an incoherent broadband cavity enhanced absorption spectrometer, Atmos. Chem. Phys., 8, 7779-7793, doi:10.5194/acp-8-7779-2008, 2008.
Washenfelder, R. A., Young, C. J., Brown, S. S., Angevine, W. M., Atlas, E. L., Blake, D. R., Bon, D. M., Cubison, M. J., de Gouw, J. A., Dusanter, S., Flynn, J., Gilman, J. B., Graus, M., Griffith, S., Grossberg, N., Hayes, P. L., Jimenez, J. L., Kuster, W. C., Lefer, B. L., Pollack, I. B., Ryerson, T. B., Stark, H., Stevens, P. S., and Trainer, M. K.: The glyoxal budget and its contribution to organic aerosol for Los Angeles, California, during CalNex 2010, J. Geophys. Res., 116, D00V02, doi:10.1029/2011JD016314, 2011a.

Washenfelder, R. A., Wagner, N. L., Dube, W. P., and Brown, S. S.: Measurement of atmospheric ozone by cavity ring-down spectroscopy, Environ. Sci. Technol., 45, 2938-2944, 2011 b.

Washenfelder, R. A., Flores, J. M., Brock, C. A., Brown, S. S., and Rudich, Y.: Broadband measurements of aerosol extinction in the ultraviolet spectral region, Atmos. Meas. Tech., 6, 861-877, doi:10.5194/amt-6-861-2013, 2013.

Watt, R. S., Laurila, T., Kaminski, C. F., and Hult, J.: Cavity Enhanced Spectroscopy of High-Temperature H2O in the NearInfrared Using a Supercontinuum Light Source, Appl. Spectrosc., 63, 1389-1395, 2009.

Wild, R. J., Edwards, P. M., Dube, W. P., Baumann, K., Edgerton, E. S., Quinn, P. K., Roberts, J. M., Rollins, A. W., Veres, P. R., Warneke, C., Williams, E. J., Yuan, B., and Brown, S. S.: A measurement of total reactive nitrogen, $\mathrm{NO}_{y}$, together with $\mathrm{NO}_{2}$, $\mathrm{NO}$, and $\mathrm{O}_{3}$ via Cavity Ring-down Spectroscopy, Environ. Sci. Technol., 48, 9609-9615, doi:10.1021/es501896w, 2014.

Yokelson, R. J., Karl, T., Artaxo, P., Blake, D. R., Christian, T. J., Griffith, D. W. T., Guenther, A., and Hao, W. M.: The Tropical Forest and Fire Emissions Experiment: overview and airborne fire emission factor measurements, Atmos. Chem. Phys., 7, 5175-5196, doi:10.5194/acp-7-5175-2007, 2007.

Young, C. J., Washenfelder, R. A., Roberts, J. M., Mielke, L. H., Osthoff, H. D., Tsai, C., Pikelnaya, O., Stutz, J., Veres, P. R., Cochran, A. K., VandenBoer, T. C., Flynn, J., Grossberg, N., Haman, C. L., Lefer, B., Stark, H., Graus, M., de Gouw, J., Gilman, J. B., Kuster, W. C., and Brown, S. S.: Vertically resolved measurements of nighttime radical reservoirs in Los Angeles and their contribution to the urban radical budget, Environ. Sci. Technol., 46, 10965-10973, 2012.

Zhou, X. L., Qiao, H. C., Deng, G. H., and Civerolo, K.: A method for the measurement of atmospheric HONO based on DNPH derivatization and HPLC analysis, Environ. Sci. Technol., 33, 3672-3679, 1999. 